\title{
Effect of intercropping systems on yield and its component in onion / faba bean crops.
}

\author{
Farghly, S. ${ }^{1 *}$, M.F. Mohamed ${ }^{1}$, M.H.Z. El-Dekashey ${ }^{1}$ and D.H. El-Shuwaikh ${ }^{2}$ \\ ${ }^{I}$ Department of Vegetables, Faculty of Agriculture, Assiut University, Assiut, Egypt. \\ ${ }^{2}$ Department of Agriculture Economics, Faculty of Agriculture, Assiut University, Assiut, Egypt.
}

\begin{abstract}
Intercropping system is a common method and it can increase the productivity, use efficiency of irrigation water and land and improve soil fertility. Therefore, the current investigation was conducted during 2016/2017, 2017/2018 and 2019/2020 seasons to study the effect of intercropping faba bean (main crop) -onion (secondary crop) on the yield and yield components and nutrient uptake. The experiment design was a randomized complete blocks, with three replicates. The experiment included 11 treatments of cropping system (sole faba bean, sole onion, 1 faba bean: 1 onion, 1 faba bean:2onion, 1faba bean:3onion, 2faba bean:1onion, 2faba bean:2onion, 2faba bean:3onion, 3faba bean:1onion, 3 faba bean:2onion and 3faba bean:3onion). Results showed that 1 faba bean :3onion was not significantly different as compred, with sole onion and recorded the highest value of vegetative parameters; plant height $(\mathrm{cm})$, leaf number, bulb diameter $(\mathrm{cm})$ and plant fresh weight $(\mathrm{g})$. Same trend was observed for yield and yield components, and nutrient uptake compared to other intercropping systems. However, regarding to faba bean vegetative characters, 3faba bean :1onion gave the greatest value with no significant difference comparing with sole faba bean and other intercropping systems treatments. Similar trend was observed for nitrogen, phosphorus and potassium uptake. Among all intercropping and sole faba bean treatments, 3faba bean:1onion recorded significant increase in total yield of faba bean with an increase percentage $13.51 \%, 16.55 \%$ and $13.84 \%$ during $1^{\text {st }}, 2^{\text {nd }}$, and $3^{\text {rd }}$ seasons, respectively. Moreover, the highest land equivalent ratio was obtained with 3faba bean:1onion in the three seasons, which were 1.249, 1.248 and 1.275 , respectively. This was followed by 1 faba bean: 3onion, which were $0.999,0.923$ and 1.005 in the 2016/2017, 2017/2018 and 2019/2020 seasons, respectively. Taken together, the intercropping system of 3faba bean:1onion or 1faba bean: 3onion could be againful model to obtain the greatest use efficiency of land and irrigation water.
\end{abstract}

Keywords: Allium cepa; Intercrop; land-use efficiency; Vicia faba

\section{Introduction}

Due to the growing population, great pressure is placed on available water, farmable land, biological resources, and energy to provide an adequate supply of food while preserving the integrity of ecosystem. In Egypt, the agriculture sector consumes more than $84 \%$ of water resources (El-Beltagy and Abou Hadid 2008;

\footnotetext{
*Corresponding author: Shrouk Farghly

Email: shrouk@agr.aun.edu.eg

Received: June 19, 2021; Accepted: July 23, 2021;

Published online: July 25, 2021.

(C) Published by South Valley University.

This is an open access article licensed under cc)(이이
}

Refai et al., 2019). Water scarcity is an increasingly serious phenomenon and required irrigation water for agriculture is often insufficient regarding the increasing human demand. Also, in Egypt, water resources are limited and restrict crop production especially in the newly reclaimed soils. Moreover, due to climate change, the loss of arable land due to either salinization or drought has posed a major challenge for maintaining food for the growing population (Mostafa et al., 2020). Therefore, it is very important to find a suitable approach to 
increase crop productivity to maintain food security. Unfortunately, Egyptian farmers used to apply excessive amounts of nitrogen fertilization in order to increase the crop productivity. Along with such a trend, researchers are aware beside the increasing costs of chemical fertilizers, it causes damage to our ecosystem, atmosphere, as well as human's health (Goyal et al., 2005; Chen and Liu 2015; Mostafa et al., 2021).

Intercropping is defined as growing two or more crop species in the same area at the same time and has widely been utilized throughout the history of agriculture. It has been used to enhance crop yield and to increase the efficiency of land, water, as well as a strategy to mitigate risk (Bybee-Finley and Ryan, 2018). However, growing crop species have different growth periods and have complementary resource use in time defined as relay-intercropping systems (Raza et al., 2019). The relay-intercropping system has a higher advantage than intercropping systems because in the relay-intercropping system both crops have different growth periods and have complementary resource use in time, however, under the intercropping system, both crops have similar growth periods and they required a high amount of nutrients for higher intercrop productivity (Raza et al., 2019). In most cases, faba bean seeds are sown during October, while onion seedlings are transplanting during December. Onion (Allium cepa L.) is one of the most important vegetable crops in Egypt for both exportation and local consumption, as well as it has several pharmacological activities (Hefzy et al., 2020). Moreover, faba bean has potential source of nutrition and as a nitrogen fixing could also play an essential role in increasing soil fertility and is capable satisfying its nitrogen requirements largely from the atmosphere (Olfati and Malakouti 2013; El-Kholy et al., 2019). Consequently, the current investigation aimed to study the effect of various intercropping systems on production and yields of faba bean and onion, nutrient uptake, and use efficiency of land and water.

\section{Materials and methods}

\subsection{Plant materials}

Faba bean (Vicia faba L.) cultivar Sakha-1 (main crop) and onion (Alium cepa L.) cultivar Giza6(secondary crop) were used in the current investigation during growing seasons of 2016/2017, 2017/2018, and 2019/2020 at the Experimental Farm of Faculty of Agriculture, Assiut University, Assiut, Egypt (Latitude 270, $18^{\prime}$ and Longitude $310^{\circ}, 18^{\prime}$ and the Altitude $70 \mathrm{~m}$ above sea level). The physical and chemical properties of the experimental soil were determined by the standard method reported by Jackson (1973) and carried out at the Central Lab. Of the Faculty of Agriculture, Assiut University, Assiut, Egypt and the obtained results are presented in Table 1.

\subsection{Growth conditions and experimental design}

Two crops namely faba bean and onion were used in the current intercropping study. Seeds of faba bean were sown in the third week of October in the first season, however, in the second and third seasons, seeds were sown in the first week of November. Onion seedlings were planted in the third week of November during the 2016/2017 season and in the first week of December during the 2017/2018 and 2019/2020 seasons. Plants were harvested in the third week of April during the three seasons. The experiment was a randomized complete blocks design with three replicates. The plot area was $9 \mathrm{~m}^{2}$; where each plot consisted of four ridges $3.5 \mathrm{~m}$ long and 60 $\mathrm{cm}$ wide. The experiment consisted of 11 treatments as follows:

1- Sole Faba bean

2- Sole onion

3- 1faba bean:1onion

4- 1faba bean:2onion

5- 1faba bean:3onion 
6- 2faba bean:1onion

7- 2faba bean:2onion

8- 2faba bean:3onion

9- 3faba bean:1onion

10- 3faba bean:2onion

11- 3faba bean:3onion.

Table 1. Chemical and physical properties of the representative composite soil sample from the surface $(0-30 \mathrm{~cm})$ of the field experimental site.

\begin{tabular}{|c|c|c|c|}
\hline \multirow{3}{*}{ Characteristic } & \multicolumn{3}{|c|}{ Seasons } \\
\hline & $2016 / 2017$ & $2017 / 2018$ & $2019 / 2020$ \\
\hline & \multicolumn{3}{|c|}{ Chemical properties } \\
\hline $\mathrm{pH}(1: 1)$ & 7.5 & 8.1 & 7.2 \\
\hline $\mathrm{EC} \mathrm{ds/m}$ & 1.1 & 1.35 & 1.35 \\
\hline Total N (\%) & 1.72 & 1.80 & 1.66 \\
\hline $\mathrm{P}$ & 12.2 & 11.20 & 11.20 \\
\hline $\mathrm{K}$ & 325 & 325 & 312 \\
\hline $\mathrm{Fe}$ & 8.6 & 8.2 & 8.2 \\
\hline $\mathrm{Mn}$ & 12 & 13.2 & 13.2 \\
\hline \multirow[t]{2}{*}{$\mathrm{Zn}$} & 1.2 & 1.5 & 1.2 \\
\hline & \multicolumn{3}{|c|}{ Physical properties } \\
\hline Clay $(\%)$ & 47 & 46.5 & 46 \\
\hline Silt $(\%)$ & 29.2 & 28.3 & 28.3 \\
\hline Sand (\%) & 21 & 19.3 & 19.3 \\
\hline Total $\mathrm{CaCO}_{3}(\%$ & 3.5 & 3.13 & 3.30 \\
\hline
\end{tabular}

Chemical fertilizers were added as follows:

Nitrogen fertilizer was added in the form of ammonium nitrate $(33.5 \% \mathrm{~N})$ at the rate of $69.5 \mathrm{~kg}$ $\mathrm{N} /$ fed. Phosphorus was added at the rate of $23.25 \mathrm{~kg}$ $\mathrm{P} 2 \mathrm{O} 5 / \mathrm{fed}$ in the form of granular superphosphate (15\% P2O5). The other agriculture practices were carried out according to the onion and faba bean extension guide - Ministry of Agriculture, Egypt.

\subsection{Faba bean vegetative characters}

A random sample of five plants were taken from each plot on March $1^{\text {st }}$ in each of three seasons of the study to determine plant height $(\mathrm{cm})$, number of branches/plant, number of pods/plant and pods weight/plant $(\mathrm{g})$.

\subsubsection{Faba bean harvesting characters}

A random sample of five plants was taken from each plot on April $19^{\text {st }}$, to April $19^{\text {th }}$ in each of three seasons of the study to determine the number of branches/plant, number of pods/plant, pods weight/plant(g), and 100-seeds weight(g). Total seeds yield $(\mathrm{kg} / \mathrm{fed})$; all plants from each plot were harvested to determine the total seeds yield $(\mathrm{kg} / \mathrm{fed})$.

\subsubsection{Faba bean biochemical measurements: chemical analysis.}

Twenty pods from each plot were randomly selected and then cut into 2-3 mm slices. beans slices were oven-dried at $70{ }^{\circ} \mathrm{C}$ until a constant weight was achieved. Dried beans were ground to a fine powder and accurately $0.5 \mathrm{~g}$ weighted for wet digestion using a mixture of sulfuric acid and hydrogen peroxide (Parkinson and Allen, 1975). The digested samples were used to measure nitrogen $(\mathrm{N})$, phosphorus $(\mathrm{P})$, and potassium $(\mathrm{K})$ as mentioned above.

\subsection{Onion vegetative characters}

A random sample of five plants was taken from each plot 90 days after transplanting in each of three seasons of the study to determine plant height $(\mathrm{cm})$, leaf number, plant fresh weight $(\mathrm{g})$, and bulb diameter $(\mathrm{cm})$.

\subsubsection{Onion harvesting characters}

At about $75 \%$ of the tops of the plants were down on April 19st, to April 19th in each plot, the plants were harvested and left for curing (for about 1015 days). Thereafter, shoots were removed and then random samples of 10 bulbs, each of the single-center bulbs, were taken from each plot to measured bulb diameter $(\mathrm{cm})$, neck diameter $(\mathrm{cm})$, and weight of bulb(g). Total bulbs yield (ton/fed): All bulbs harvested from each plot were weighted and data were converted into bulb yield in ton/fed. 

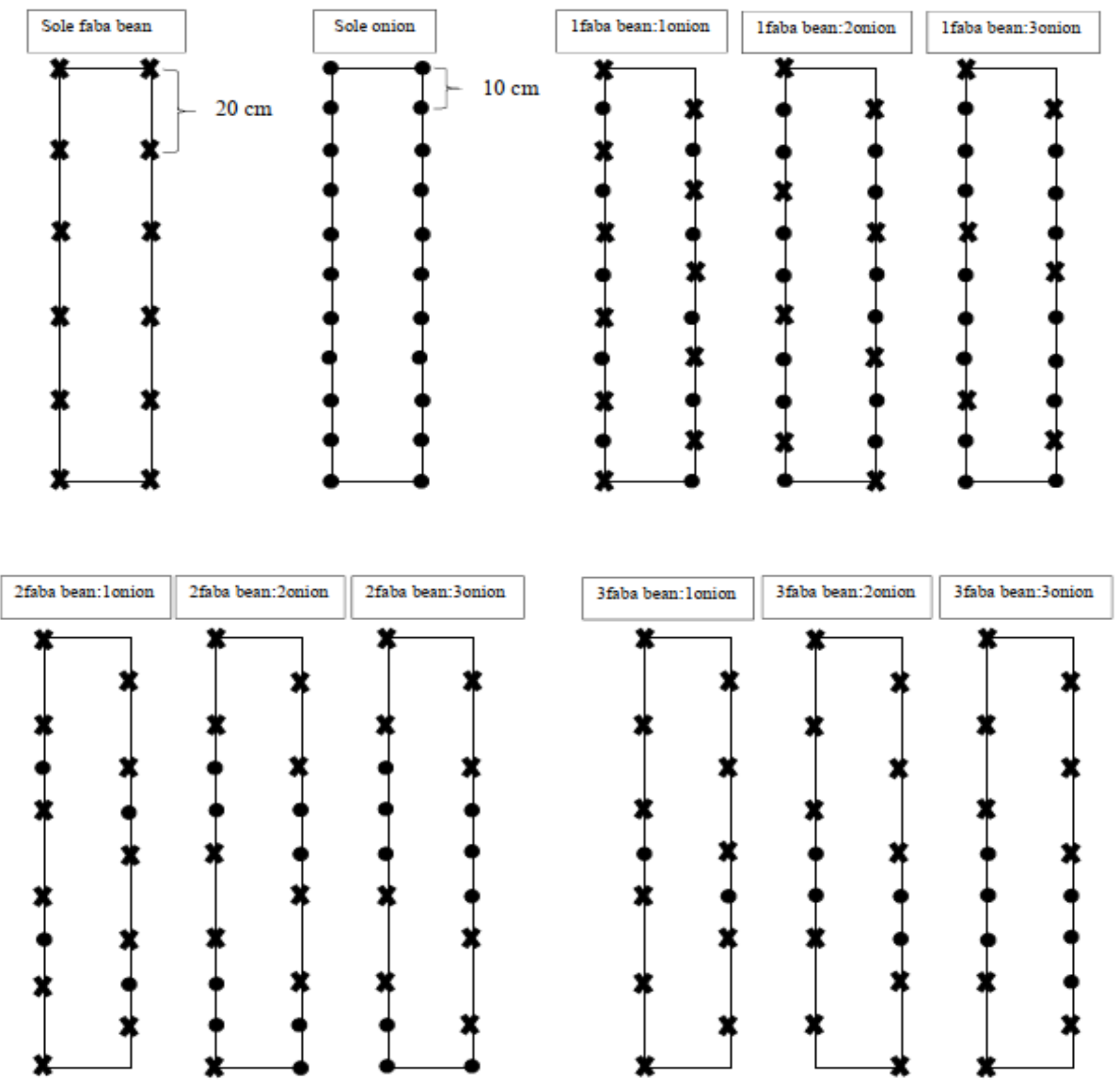


\subsubsection{Onion biochemical measurements: chemical analysis.}

Five bulbs from each plot were randomly selected and then cut into 2-3 mm slices. Bulbs slices were oven-dried at $70{ }^{\circ} \mathrm{C}$ until a constant weight was achieved. Dried bulbs were ground to a fine powder and accurately $0.5 \mathrm{~g}$ weighted for wet digestion using a mixture of sulfuric acid and hydrogen peroxide (Parkinson and Allen, 1975). The digested samples were used to measure nitrogen $(\mathrm{N})$, phosphorus $(\mathrm{P})$, and potassium $(\mathrm{K})$. $\mathrm{N}$ determination was carried out using the microKjeldahl procedure (Jones et al., 1991). Total phosphorus was determined spectrophotometrically by Milten Roy Spectronic 120 at wavelength $725 \mathrm{~nm}$ using stannous chloride reduced molybdosulphoric blue color method in the sulphuric system as described by Peters et al. (2003) and total potassium was measured by the flame photometric method using Jenway flame photometer, Model corning 400 according to the modified method of Peters et al. (2003).

\subsection{Land equivalent ratio (LER)}

Land equivalent ratio (LER) is defined as the ratio of area needed under sole cropping to one of intercropping at the same management level to produce an equivalent yield (Willey, 1979). It was calculated as follows:

$L E R=(Y a b / Y a a)+(Y b a / Y b b)$

Where $Y_{a a}=$ pure stand yield of crop a;

$\mathrm{Y}_{\mathrm{bb}}=$ pure stand yield of crop $b$;

$\mathrm{Y}_{\mathrm{ab}}=$ intercrop yield of crop $\mathrm{a}$;

$\mathrm{Y}_{\mathrm{ba}}=$ intercrop yield of crop $\mathrm{b}$

\subsection{Statistical analysis}

All obtained data were subjected to statistical analysis of variance using Statistix 8.1 software (Analytical Software, 2005). Treatment means were compared for significant differences using the Tukey test at $p=0.05$. Data are presented as the means \pm standard deviations (SD).

\section{Results}

\subsection{Faba bean vegetative characters: effect of intercropping pattern on onion vegetative parameters.}

Various intercropping systems significantly affected No. of pods lplant and Pods weight / Plant (g) of green Faba bean during 2016/2017, 2017/2018, and 2019/2020 seasons. (Fig 1, 2, 3 and 4). The maximum No. of pods weight / Plant were noted from sole faba bean (17.00 pod and $172.20 \mathrm{~g})$ in the first season, (18.33 pod and $173.87 \mathrm{~g}$ ) in the second season, and (20.53 pod and $201.53 \mathrm{~g}$ ) during third seasons. This was not significantly different from intercropping system faba bean / onion (1:1) and (2:2) during all study seasons. However, intercropping system 1faba bean: 3onion produced the lowest weight in No. of pods \plant in the three seasons. Regarding to plant height $(\mathrm{cm})$ presented data clarified that sole faba bean obtained the tallest plants, while 1 faba bean: 3 onion recorded the shortest ones during the three study seasons. Also the results indicated that there was no significant difference between 3 faba bean: 1onion and 3faba bean: 2onion in second and third season. Also, no significant difference in No. of brancheslplant between 3faba bean: 1onion and 3faba bean: 2onion in third season. On the other hand, 1 faba bean: 3 onion recorded the lowest value of No. of branchesiplant which were, 3.33,3,00 and 3.27 during all experimental seasons, respectively. 


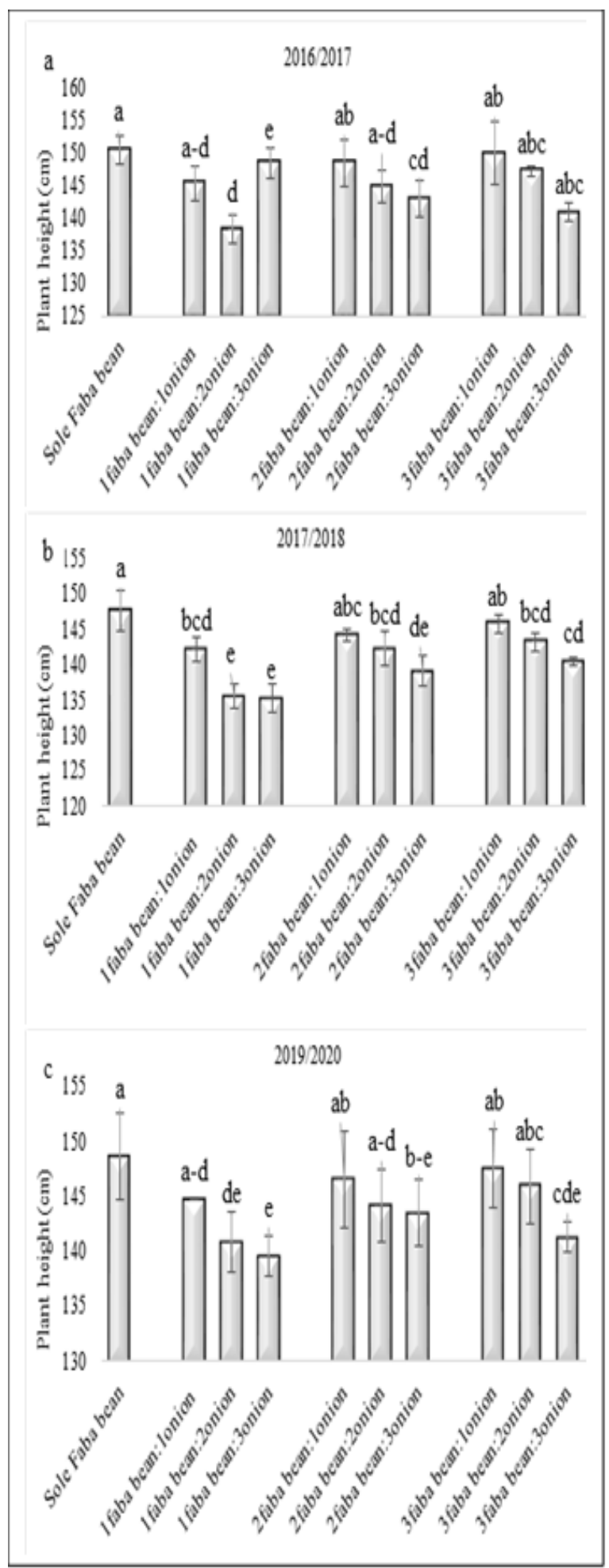

Fig 1. Influence of intercropping system on plant height (cm) of faba bean during 2016/2017 (a), 2017/2018(b), and 2019/2020(c) seasons. Data are presented as means \pm SDs and the different upper letters indicate significant differences at $\mathrm{P}<0.05$ level according to the Tukey's test.

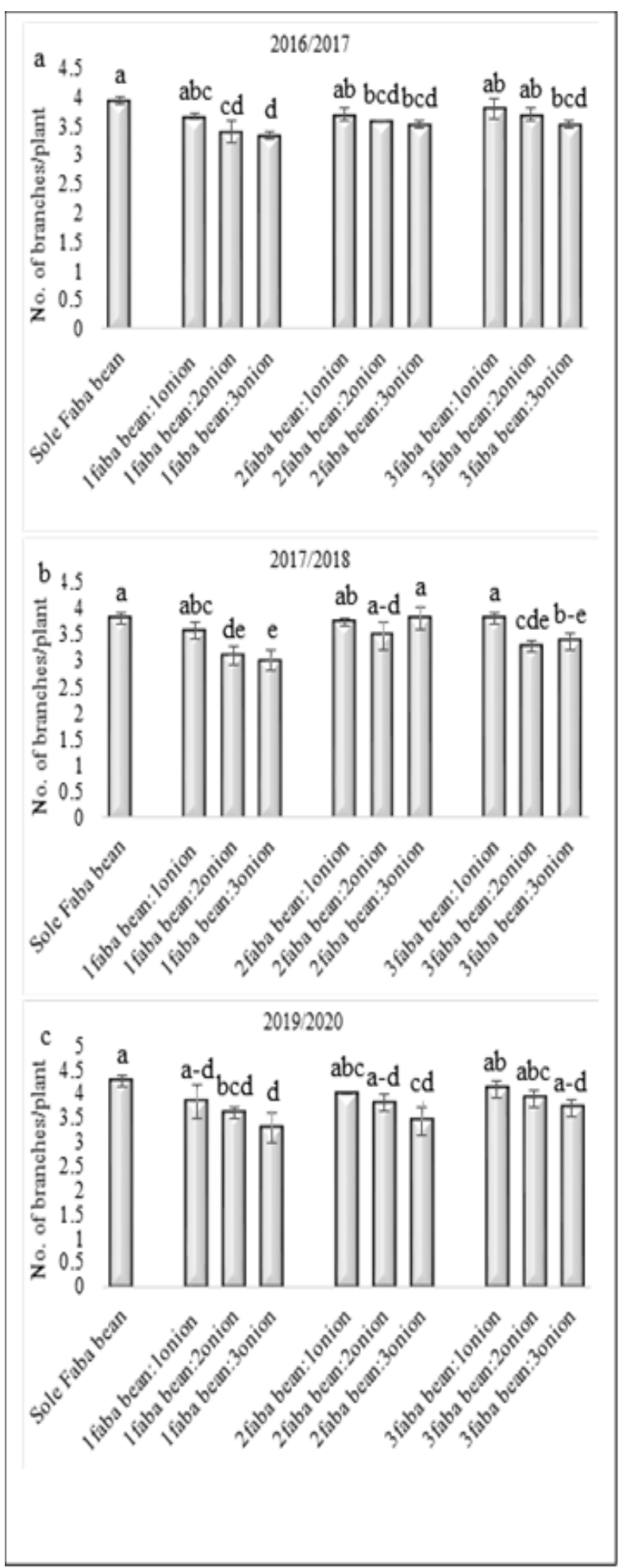

Fig 2. Influence of intercropping system on No. of branchesłplant of faba bean during 2016/2017 (a), $2017 / 2018$ (b), and 2019/2020 (c) seasons. Data are presented as means \pm SDs and the different upper letters indicate significant differences at $\mathrm{P}<0.05$ level according to the Tukey's test. 


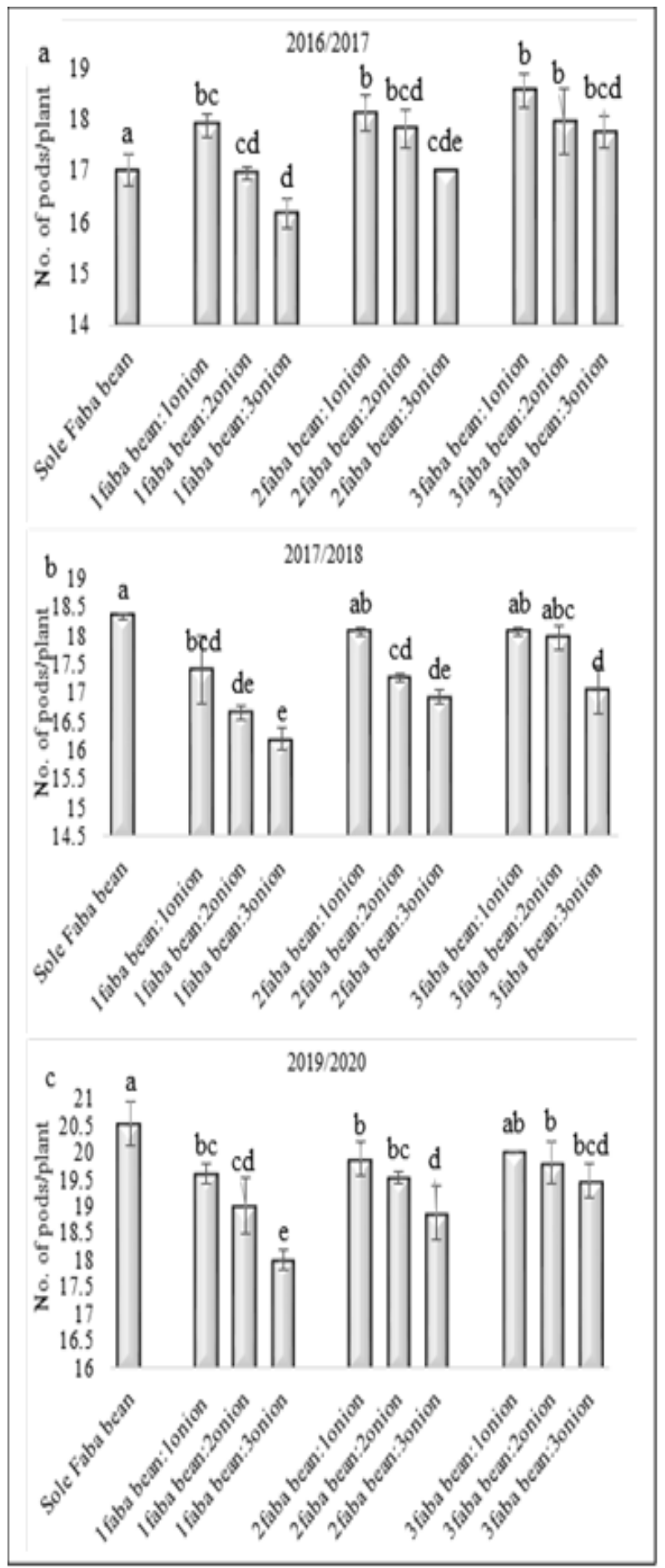

Fig 3. Influence of intercropping system on No. of pods \plant of faba bean during 2016/2017 (a), 2017/2018 (b), and 2019/2020(c) seasons. Data are presented as means \pm SDs and the different upper significant differences at $\mathrm{P}<0.05$ level according to the Tukey's test.

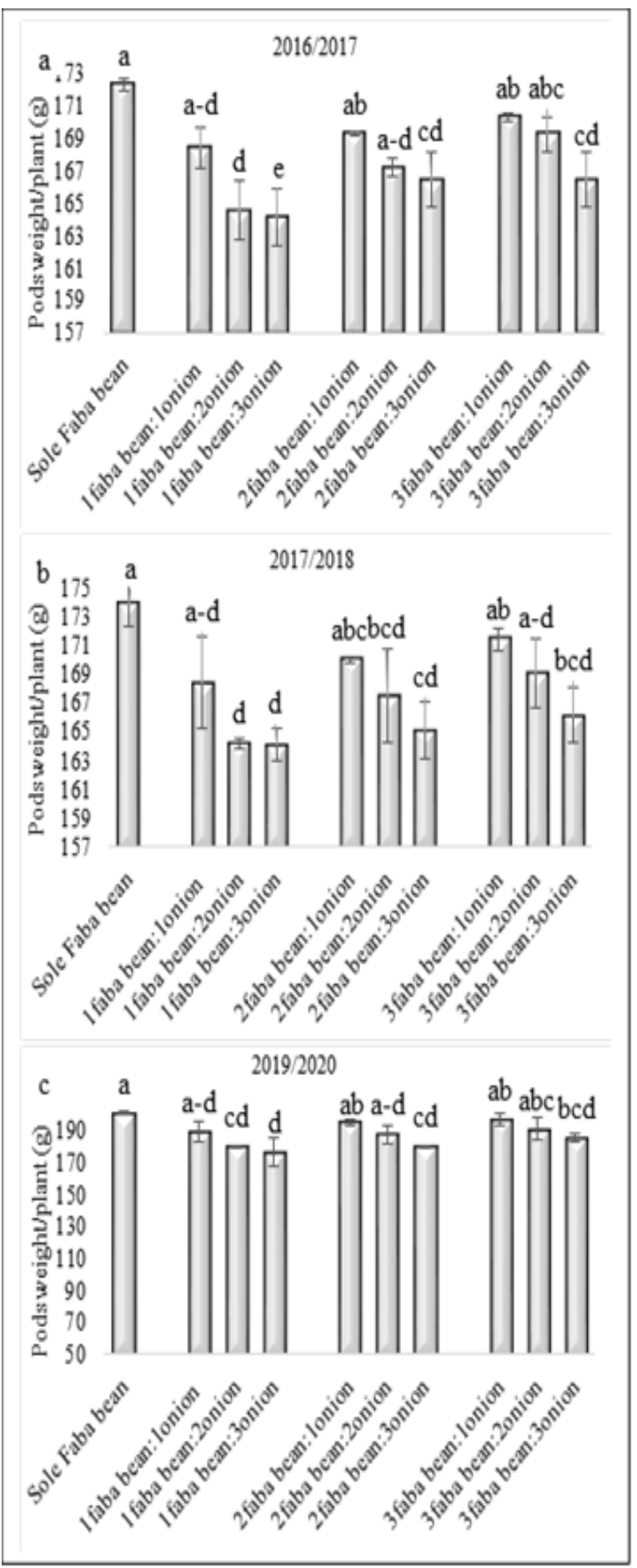

Fig 4. Influence of intercropping system on pods weightlplant (g) of faba bean during 2016/2017 (a), 2017/2018(b), and 2019/2020(c) seasons. Data are presented as means \pm SDs and the different upper letters indicate significant differences at $\mathrm{P}<0.05$ level according to the Tukey's test. 


\subsubsection{Faba bean harvesting characters}

The harvest parameters of faba bean in fig (5 - 8) revealed that No. of podsiplant and weight of 100 seeds (g) was decreased significantly during 2016/2017, 2017/2018, and 2019/2020 seasons. The greatest value of No. of podsiplant, pods weight / Plant (g) and weight of 100 seeds $(\mathrm{g})$ was associated with sole faba bean in the three seasons, which were $(17.33,40.46$ and 88.23$)$ in the first season, $(17.27,40.60$ and 85.43$)$ in the second season, and (20.57, 44.00 and 89.13) during third seasons. This was not significantly different from intercropping system 1 faba bean: 3onion during all study seasons. However, intercropping system 1faba bean: 3onion produced the lowest weight of 100 seeds ( $g$ ) in the three seasons. This trend was also observed with No. of branches\plant, during the three studied seasons. Where sole faba bean recorded the greatest value of No. of branches/plant, with no significant difference with 1 faba bean: 3onion. Similarly, intercropping system 1faba bean: 3onion gives the lowest value of No. of branchesiplant, which were $4.27,4.00$, and 4.27 during 1st, 2nd, and 3rd seasons, respectively.

The result in Fig. (9) indicted that faba bean seed yield of 3faba bean:1onion system significantly surpassed seed yield/fed of the sole cropping by $13.51 \%, 16.55 \%$ and $13,84 \%$ respectively 2016/2017, 2017/2018, and 2019/2020 seasons. On the other hand, intercropping 1faba bean: 3 onion system recorded the highest decrease percentage $(68.28 \%)$ in the third season but 1 faba bean: 2 onion recorded the greatest decrease percentage (63.60\% and 63.19\%) during first and second seasons, respectively.

\subsubsection{Faba bean biochemical measurements: chemical analysis.}

Data presented in Fig (10, 11 and 12) showed that nitrogen $(\mathrm{N})$, phosphorus $(\mathrm{P})$, and potassium $(\mathrm{K})$ percentages were determined for faba bean seeds under different intercropping systems, Results showed that with increasing the faba bean plants, nitrogen percentage was increased significantly during the growing seasons of 2016/2017, 2017/2018, and 2019/2020.In the 1st, 2nd, and 3rd seasons the greatest value of $\mathrm{N}(4.90 \%$, $4.70 \%$, and $4.81 \%$ ) was produced by sole faba bean system and the lowest value was recorded by 1 faba bean:3 onion, which were $(4.57 \%$, $4.17 \%$, and $4.40 \%$ ) during the three studied seasons, respectively. In the second and third season no significant difference was found among 2faba bean:2onion and 3faba bean: 3onion. On the other hand, data showed that no significant difference was found among 1faba bean:2onion, 2faba bean: 3onion and 3faba bean:3onion in first season.

Concerning $\mathrm{P} \%$ and $\mathrm{K} \%$, presented data clarified that sole faba bean obtained the highest $\mathrm{P}$ and $\mathrm{K}$ $\%$ during all seasons with no significant difference with 1 faba bean: 3onion and 1faba bean: 2onion in second season. On the other hand, 1 faba bean: 3 onion recorded the lowest percentage of $\mathrm{P}$ and $\mathrm{K}$ during the three studied seasons. 


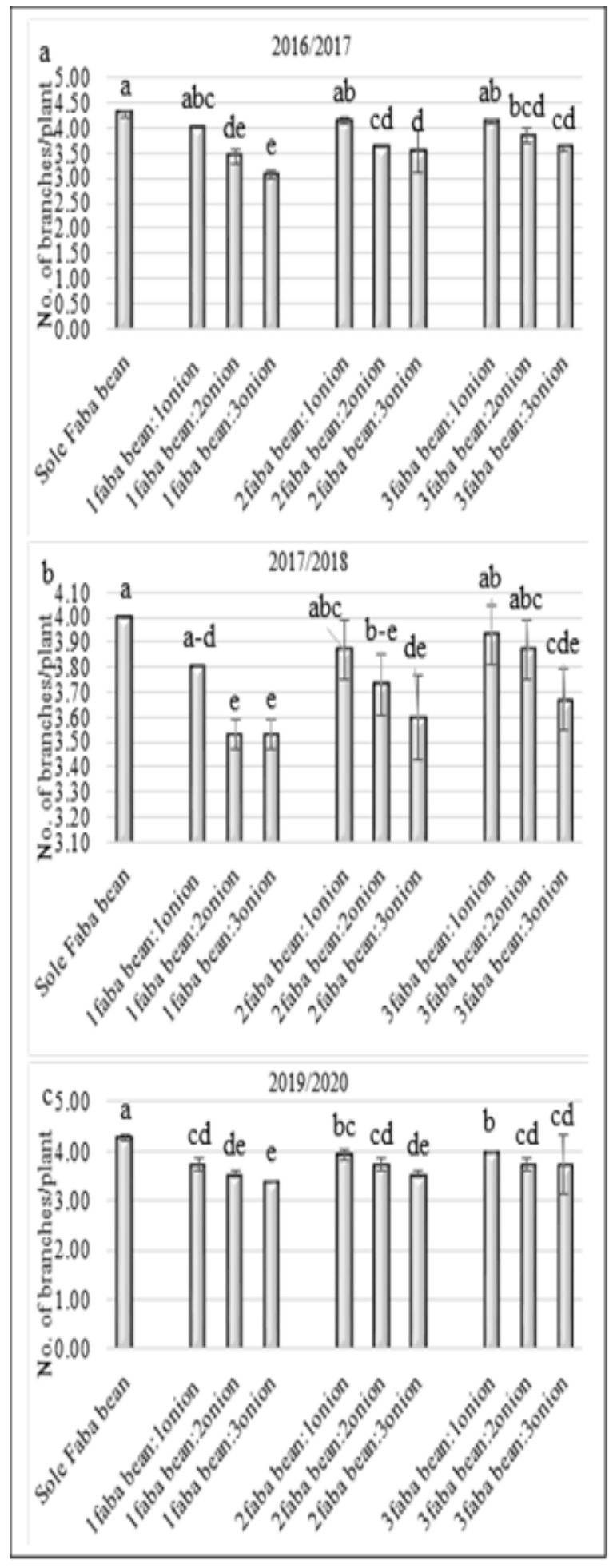

Fig 5. Influence of intercropping system on No. of branchesłplant of dry Faba bean during 2016/2017, 2017/2018, and 2019/2020 seasons. Data are presented as means \pm SDs and the different upper letters indicate significant differences at $\mathrm{P}<0.05$ level according to the Tukey's test.

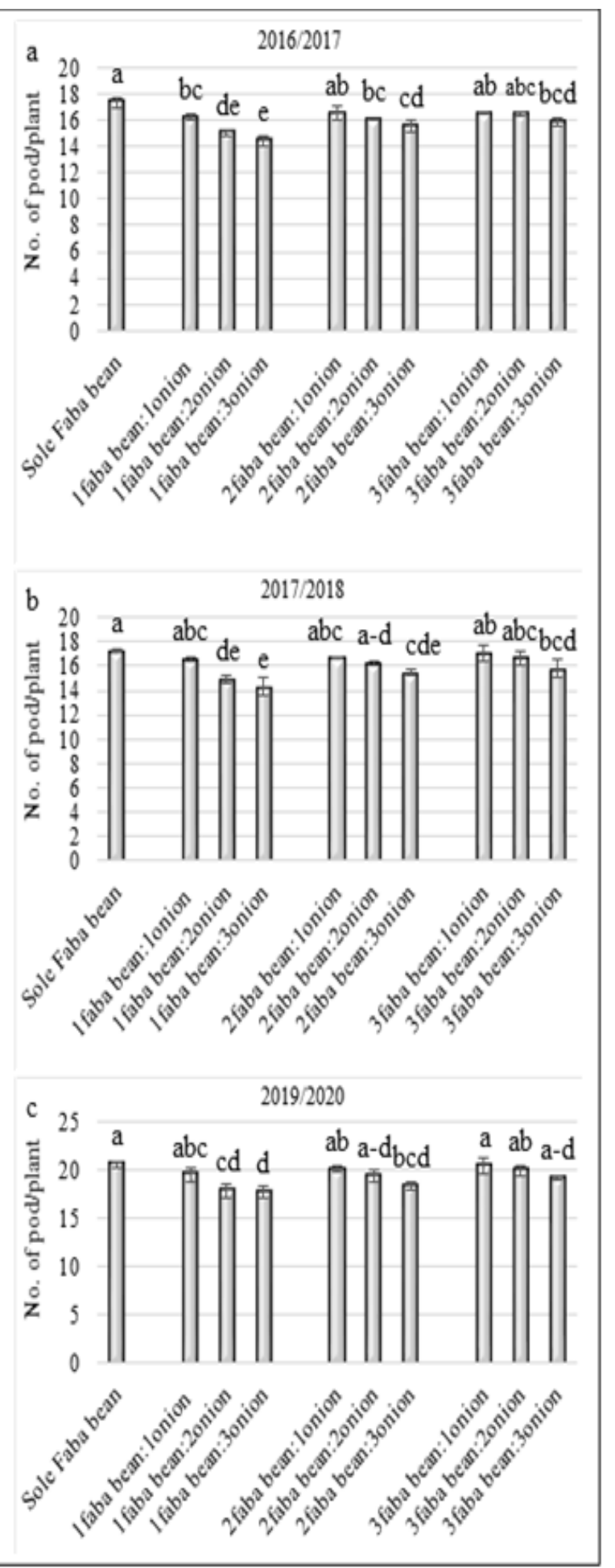

Fig 6. Influence of intercropping system on No. of pod\plant of dry Faba bean during 2016/2017(a), 2017/2018 (b), and 2019/2020(C) seasons. Data are presented as means \pm SDs and the different upper letters indicate significant differences at $\mathrm{P}<0.05$ level according to the Tukey test. 


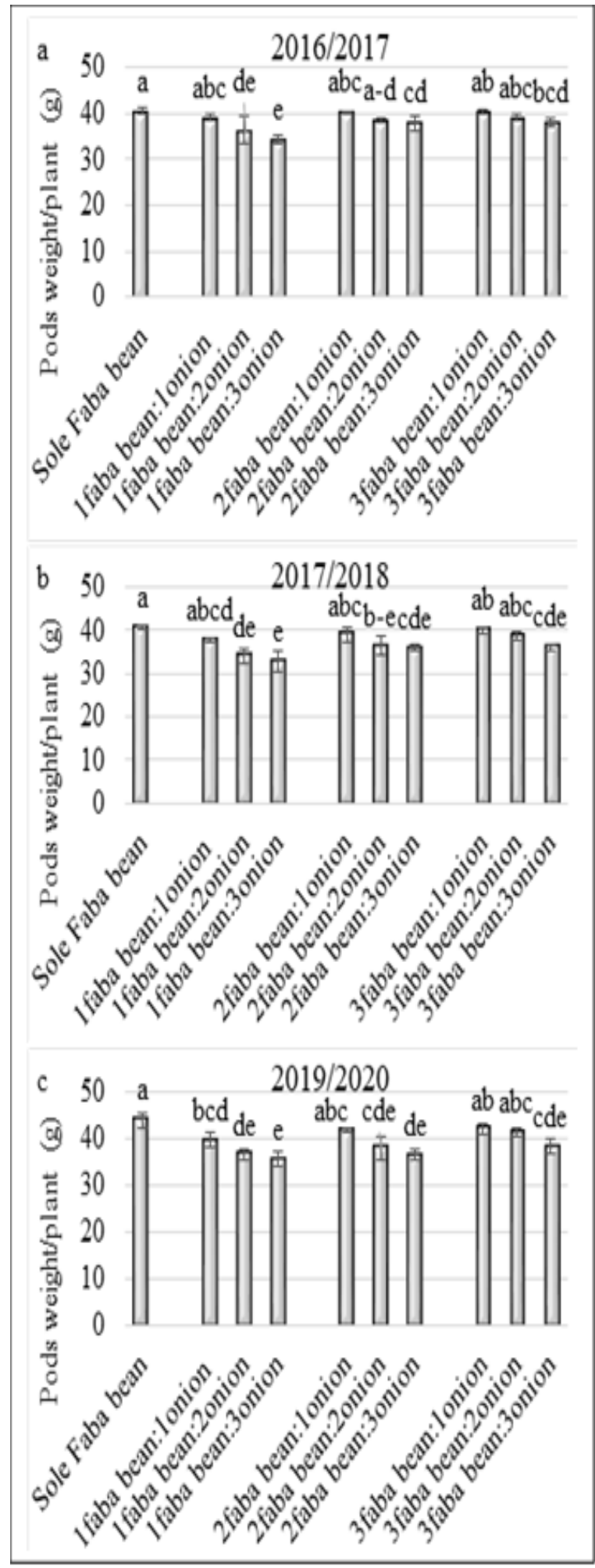

Fig 7. Influence of intercropping system on pods weight Iplant (g) of dry Faba bean during 2016/2017, 2017/2018, and 2019/2020 seasons. Data are presented as means \pm SDs and the different upper letters indicate significant differences at $\mathrm{P}<0.05$ level according to the Tukey's test.

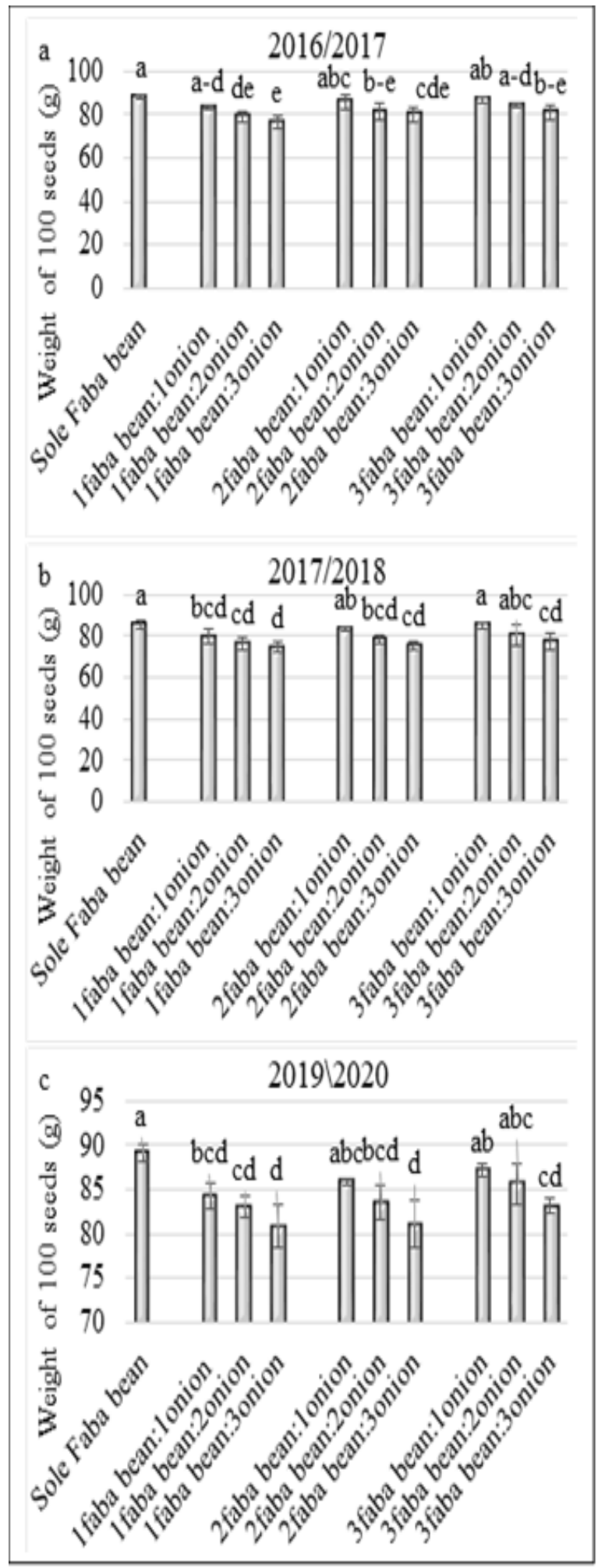

Fig 8. Influence of intercropping system on weight of 100 seeds (g) of dry Faba bean during 2016/2017, 2017/2018, and 2019/2020 seasons. Data are presented as means \pm SDs and the different upper letters indicate significant differences at $\mathrm{P}<0.05$ level according to the Tukey's tes 


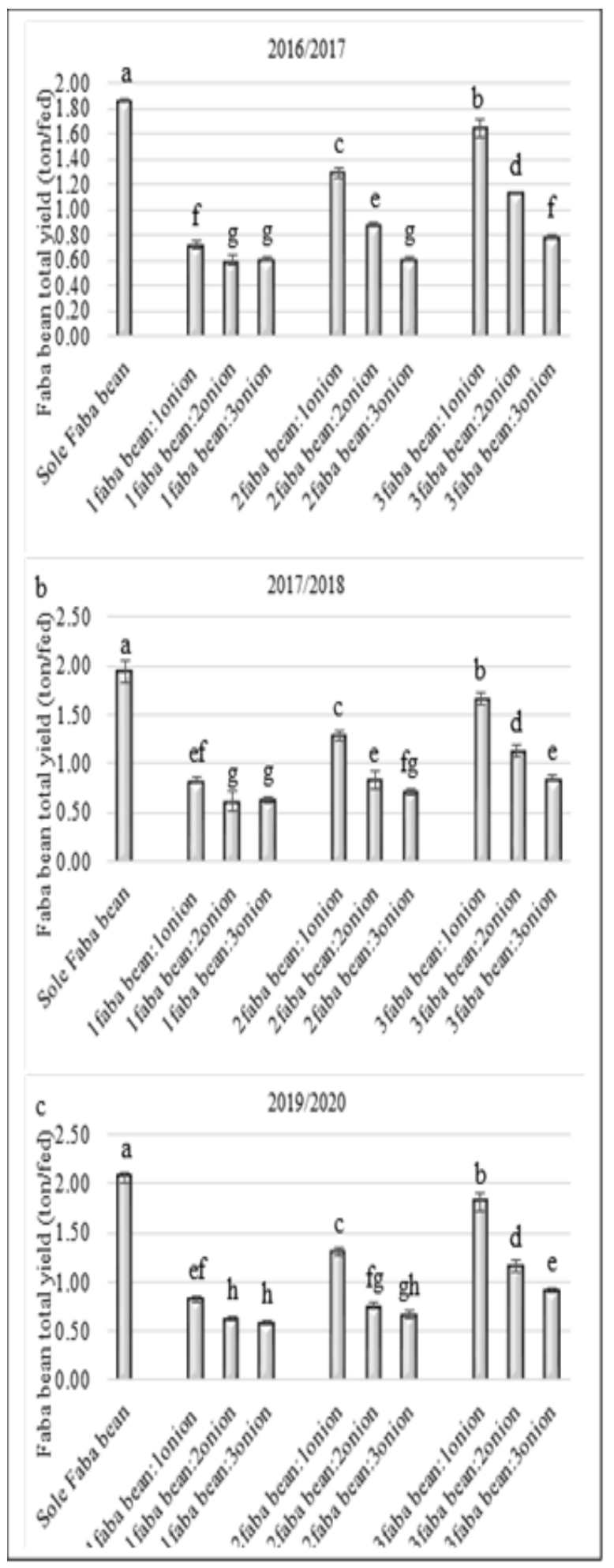

Fig 9. The total yield of faba bean as affected by the intercropping system during the 2016/2017 (a), 2017/2018 (b), and 2019/2020 (c) seasons. Data are presented as means \pm SDs and the different upper letters indicate significant differences at $\mathrm{P}<0.05$ level according to the Tukey's test.

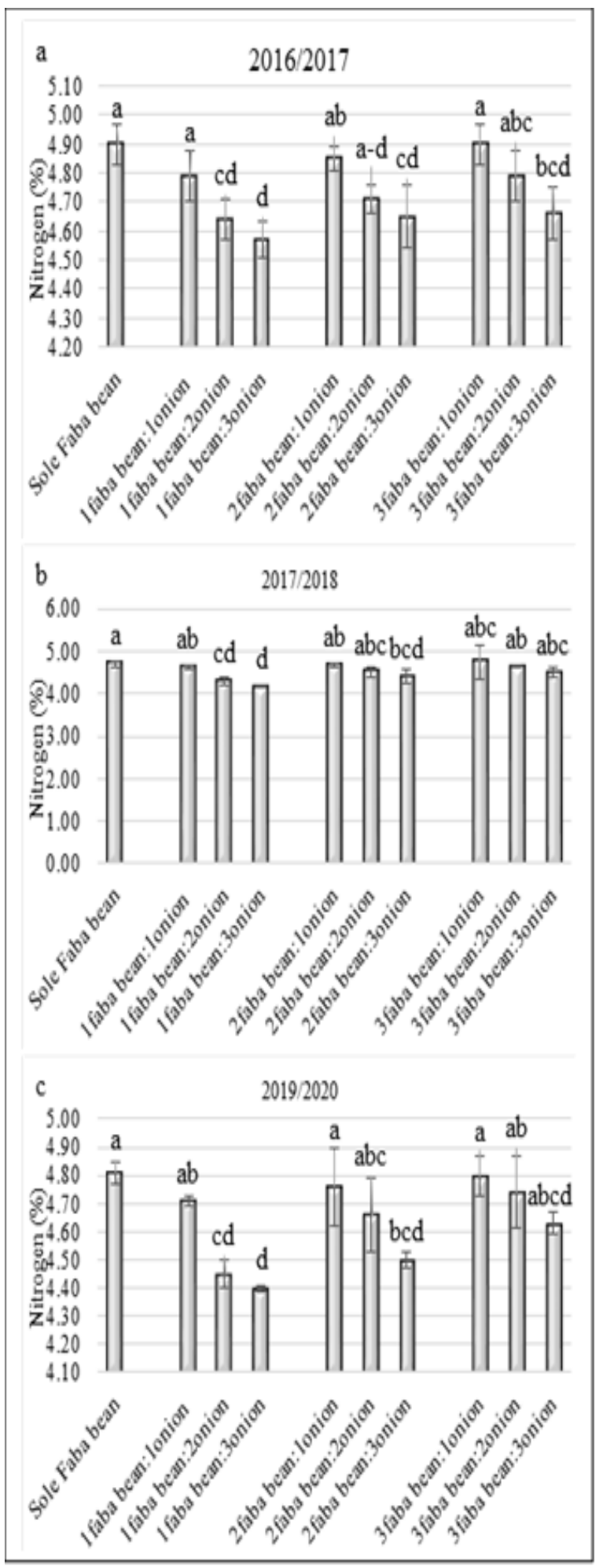

Fig 10. Influence of intercropping system on N\%, of Faba bean during 2016/2017, 2017/2018, and 2019/2020 seasons. Data are presented as means \pm SDs and the different upper letters indicate significant differences at $\mathrm{P}<0.05$ level according to the Tukey's test. 


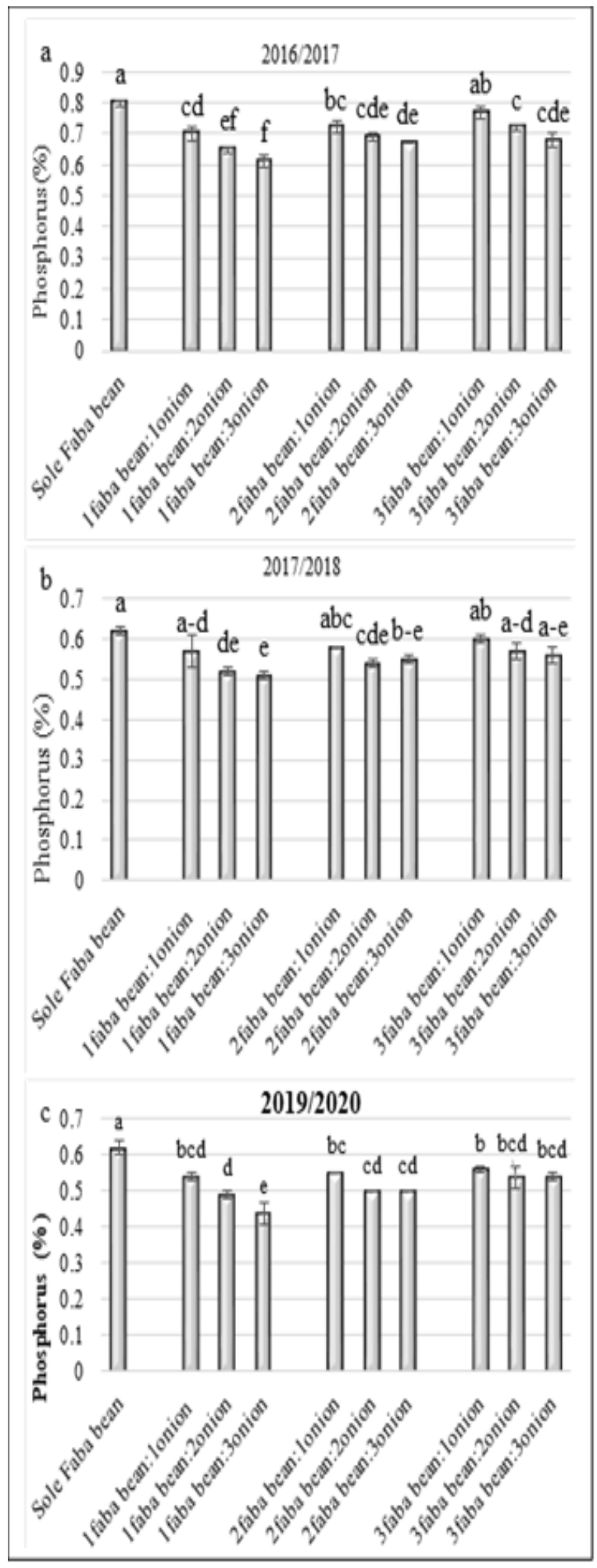

Fig 11. Influence of intercropping system on $\mathrm{P} \%$ of Faba bean during 2016/2017, 2017/2018, and 2019/2020 seasons. Data are presented as means \pm SDs and the different upper letters indicate significant differences at $\mathrm{P}<0.05$ level according to the Tukey's test.

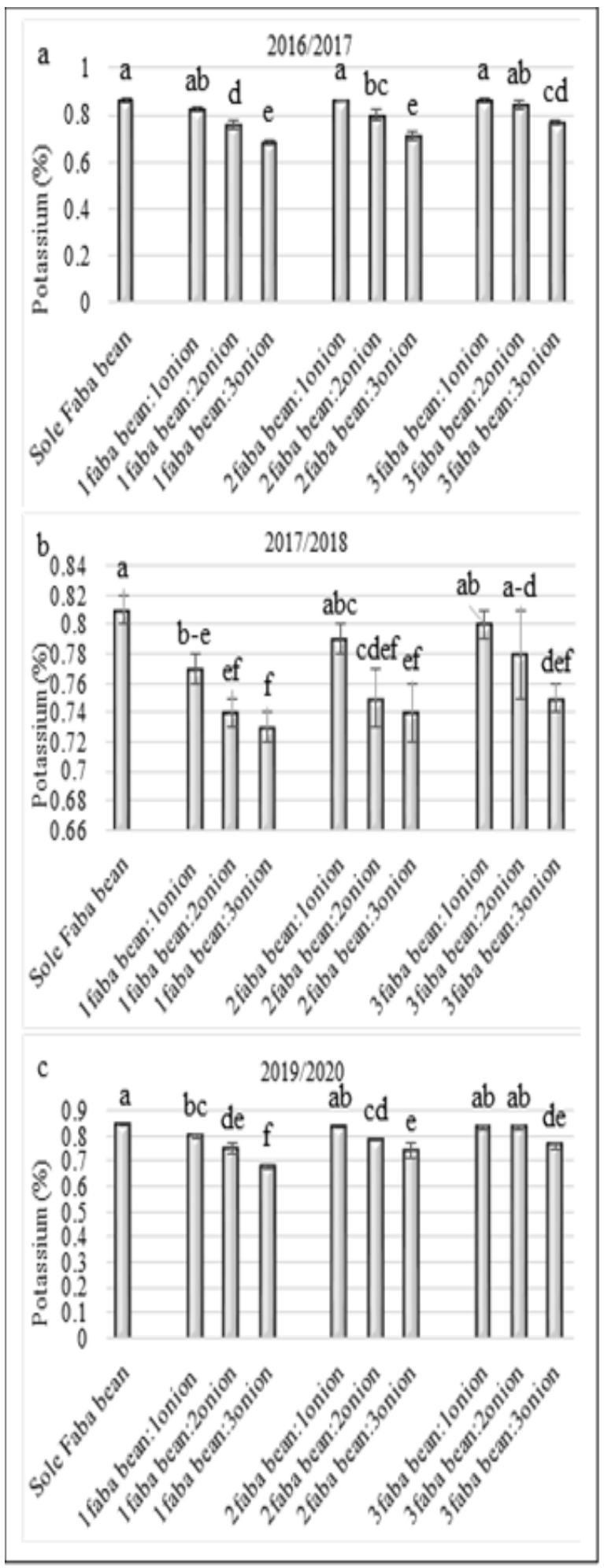

Fig 12. Influence of intercropping system on $\mathrm{K} \%$ of Faba bean during 2016/2017, 2017/2018, and 2019/2020 seasons. Data are presented as means \pm SDs and the different upper letters indicate significant differences at $\mathrm{P}<0.05$ level according to the Tukey's test. 


\subsection{Onion vegetative characters: effect of intercropping pattern on onion vegetative parameters.}

The vegetative parameters of onion; plant height (cm), leaf number, bulb diameter $(\mathrm{cm})$, and plant fresh weight $(\mathrm{g})$ alterations in response to various intercropping systems were measured and data were presented in Fig 13, 14, 15 and 16 The data showed that intercropping treatments $(\mathrm{p}<0.01)$ affected the vegetative parameters of onion vegetative traits. In general, as shown in Fig (13), the tallest plants were found in sole grown onion in the three seasons, statistically comparabl plants were detected in intercropping of faba bean: onion (1:3) during three seasons. Intercropping of faba bean $1: 1$ or $1: 2$ or $1: 3$, in addition to faba bean: onion 2:3 were also comparable. Meanwhile, the lowest value of onion plant height was obtained when sowing 3 fabe bean seeds with one transplant of onion. This intercropping treatment had olants shorter by $7.87,10.03$, and $12.54 \%$ compared to sole onion during the three seasons. Comparable short plants were found for faba /onion intercropping 1:1, 2:1, $3: 1$ and $2: 2$.

Data of leaf number, bulb diameter and plant fresh weight in fig 14, 15 and 16 show a trend that is largely similar to plant height. There was no significant difference in the leaf number between the onion grown as sole crop and onion intercropped as 1 faba bean with 2 or 3 onion plants in 2016/2017, 2018/2019, and 2019/2020 seasons. Results revealed that use 2 or 3 faba bean plants grown with 1 onion plant recorded the lowest value for the leaf number among all treatments.

Bulbs diameter was the largest when growing onion as sole crop (Fig 15). Consistently, bulb diameter of faba bean /onion as 1:2 and 1:3 showed no significant deviation from those bulbs producted as sole onion crop. Bulb had the least diameter when produced as faba bean /onion 3:1 intercropping treatment. Constant comparable values were found in bean/onion 2:1 intercropping. Fresh weight of onion plants was the highest when produced as sole crop. None of the intercropping treatments showed a plant fresh weight that was comparable to sole cropping of onion and consistent over the three study seasons. The lowest plant fresh weight was observed in onion produced by plants intercropped with faba bean as 2 or 3 faba :1 onion.

\subsubsection{Onion harvesting characters}

Various intercropping systems significantly affected the bulb diameter, neck diameter, and bulb fresh weight during 2016/2017, 2017/2018, and 2019/2020 seasons (Fig 17, 18 and 19). The maximum bulb and neck diameter were noted from sole onion $(6.86 \mathrm{~cm}$ and $1.79 \mathrm{~cm}$ in the first season, $6.93 \mathrm{~cm}$ and $1.52 \mathrm{~cm}$ in the second season, and $6.76 \mathrm{~cm}$ and $1.65 \mathrm{~cm}$ during third seasons). This was not significantly different from intercropping system 1faba bean:3onion during all study seasons. However, intercropping system 3faba bean:1onion produced the smallest bulb and neck diameter in the three seasons. The same trend was observed in the bulb fresh weight during all experimental seasons. Where sole onion recorded the greatest value of bulb fresh weight with no significant difference with 1 faba bean:3onion. Similarly, intercropping system 3 faba bean:1onion gives the smallest bulb fresh weight with reduction percentage $41.63 \%$, $24.06 \%$, and $17.69 \%$ during $1 \mathrm{st}, 2 \mathrm{nd}$, and $3 \mathrm{rd}$ seasons, respectively.

Regarding to the total bulb yield as affected by the various intercropping system, the obtained results in (Fig. 20) revealed that various intercropping system significantly affected the total yield of onion in three experimental seasons. After sole onion, transplanting three onion seedlings and sowing one faba bean seed showed highest average of total bulb yield compared to other intercropping systems. Compared to sole onion, 3onion:1faba bean recorded a decrease 
percentage of $37.25 \%, 45.53 \%$ and $31.17 \%$ in the 1st, 2nd and 3rd seasons, respectively. On the other hand, intercropping 1 seedling onion and 3

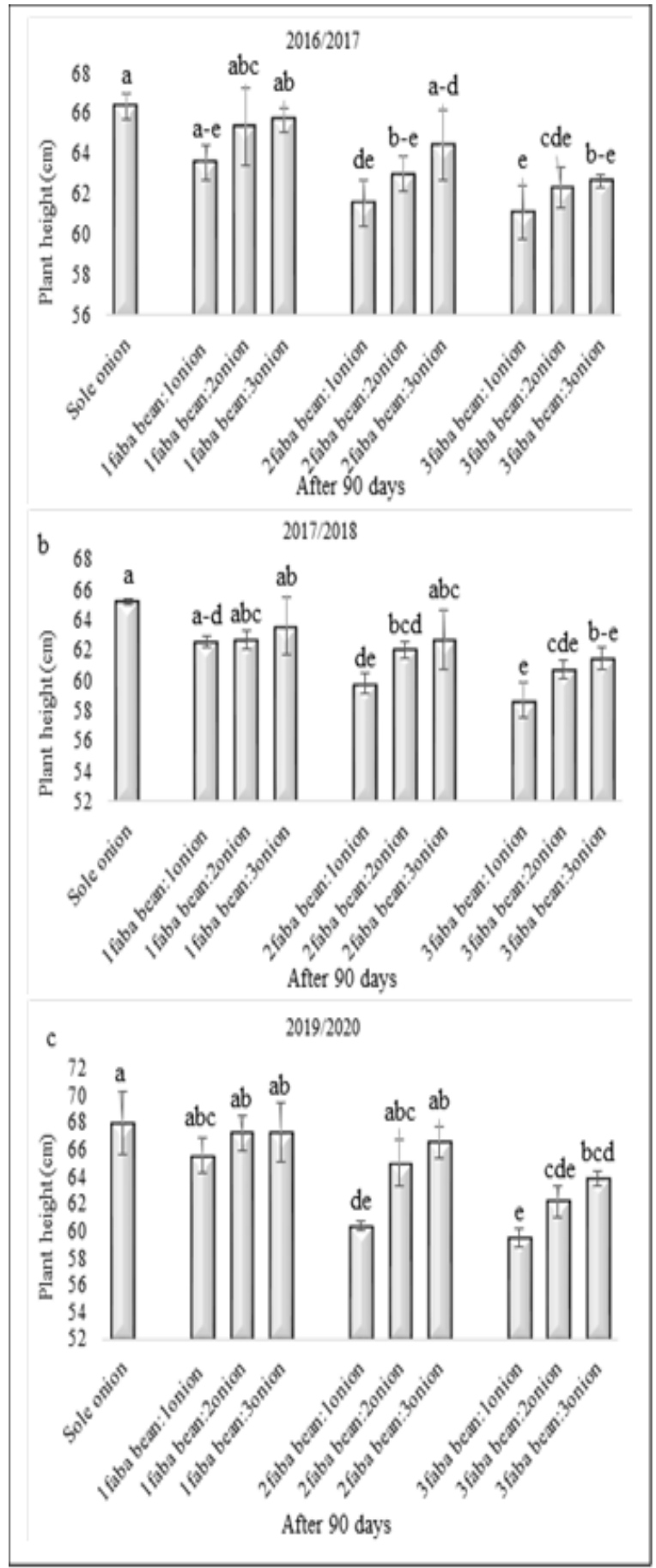

Fig 13. Influence of intercropping system on plant height (cm) of onion during 2016/2017 (a) , 2017/2018(b), and 2019/2020(c) seasons. Data are presented as means \pm SDs and the different upper letters indicate significant differences at $\mathrm{P}<0.05$ level according to the Tukey test. faba bean plants recorded the highest decrease percentage $(88 \%, 92.72 \%$ and $86.34 \%$ during study seasons, respectively).

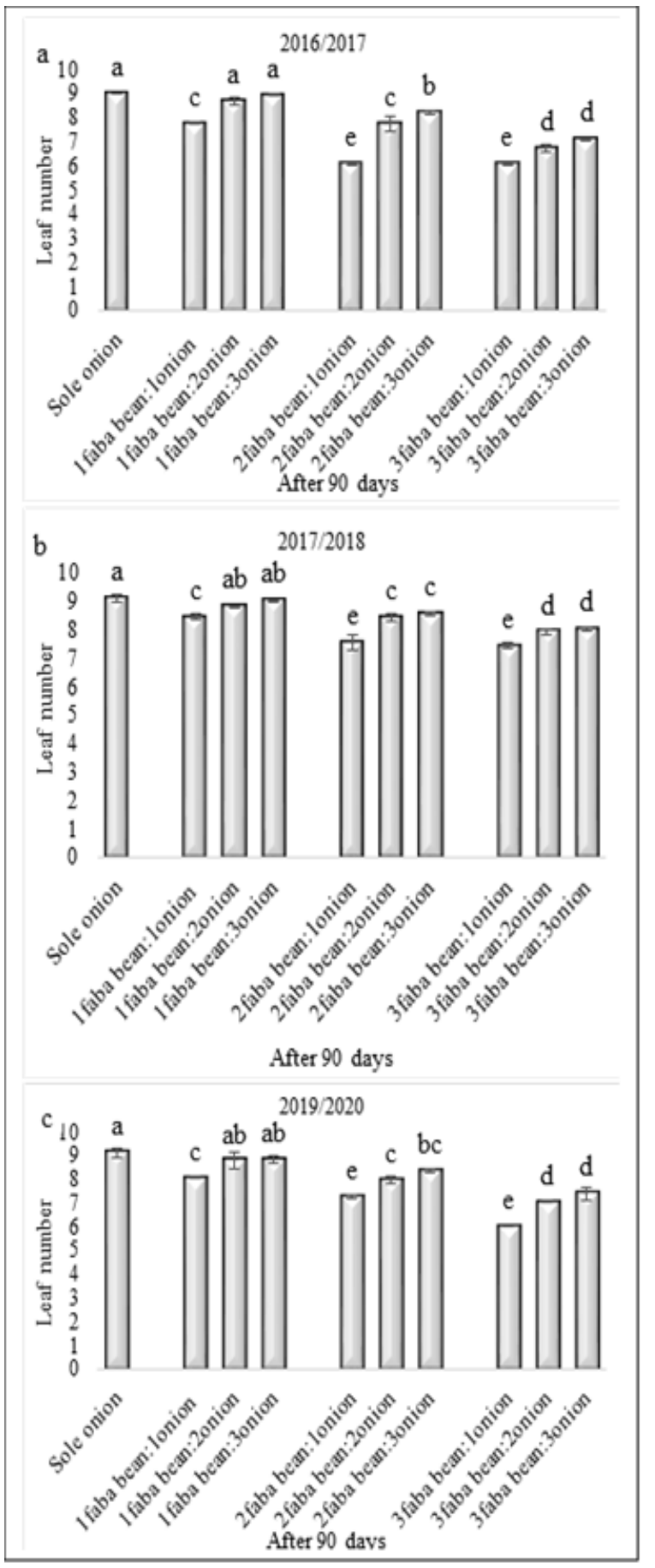

Fig 14. Influence of intercropping system on Leaf number of onion during 2016/2017 (a) , 2017/2018(b), and 2019/2020(c) seasons. Data are presented as means \pm SDs and the different upper letters indicate significant differences at $\mathrm{P}<0.05$ level according to the Tukey test. 


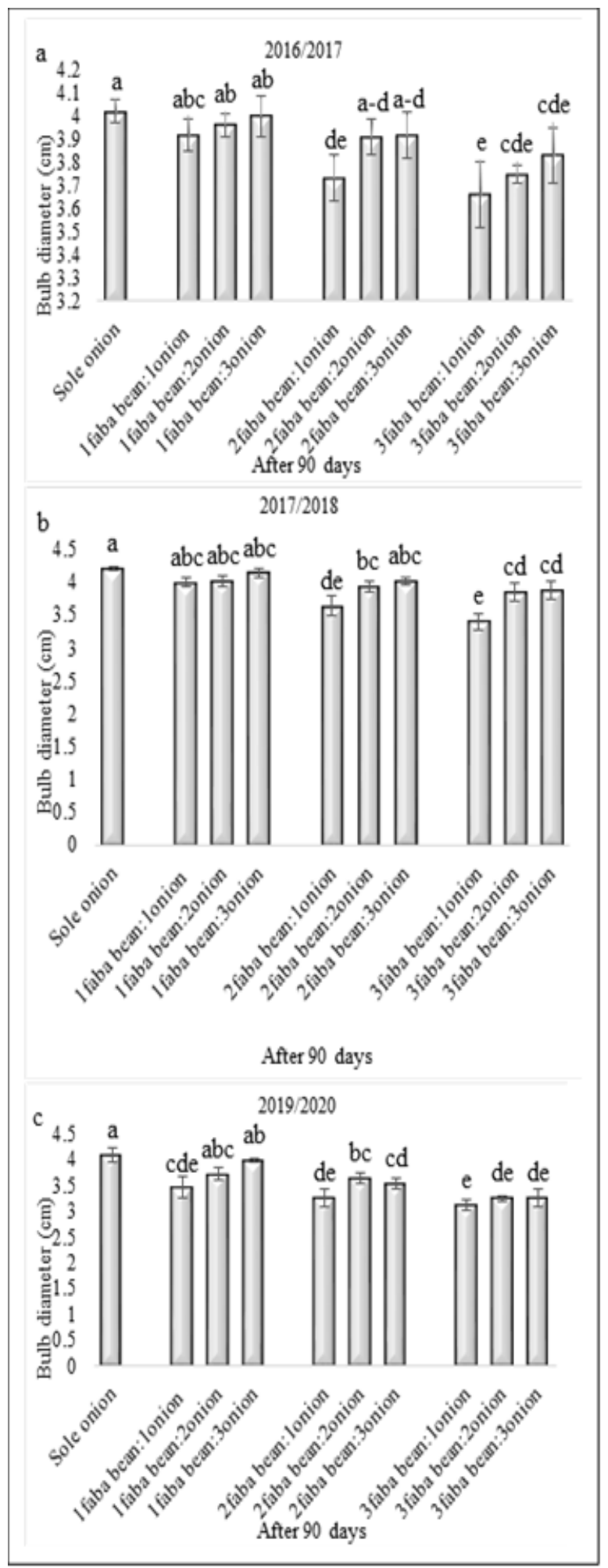

Fig 15. Influence of intercropping system on Bulb diameter (cm) of onion during 2016/2017 (a) , 2017/2018(b), and 2019/2020(c) seasons. Data are presented as means \pm SDs and the different upper letters indicate significant differences at $\mathrm{P}<0.05$ level according to the Tukey's test.

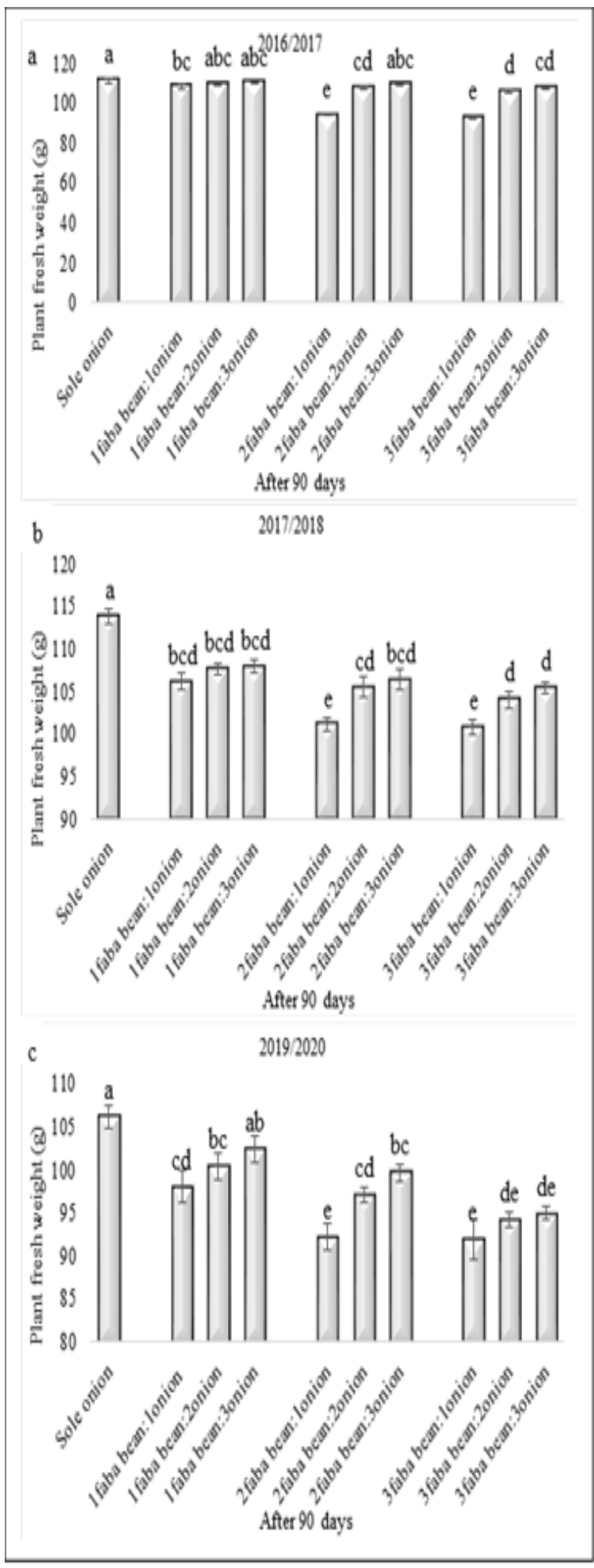

Fig 16. Influence of intercropping system on Plant fresh weight (g) of onion during 2016/2017 (a) , 2017/2018(b), and 2019/2020(c) seasons. Data are presented as means \pm SDs and the different upper letters indicate significant differences at $\mathrm{P}<0.05$ level according to the Tukey's test. 


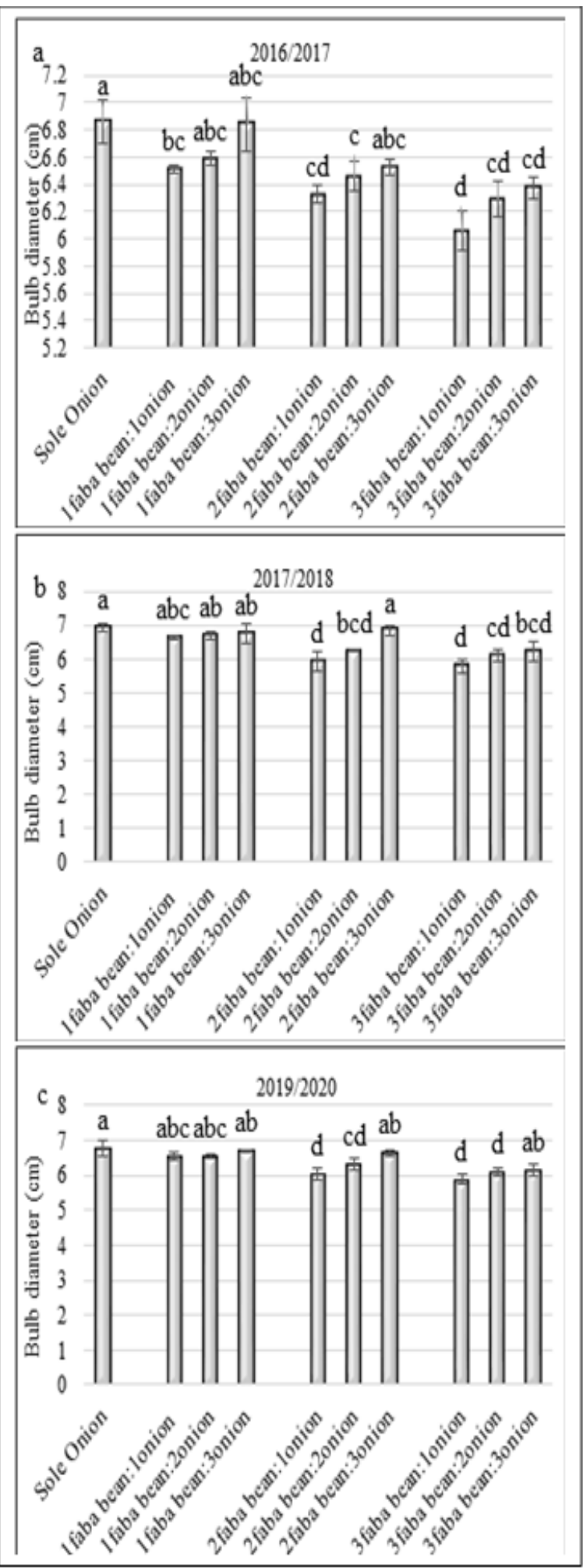

Fig 17. Influence of intercropping system on Bulb diameter (cm), of dry Onion during 2016/2017(a), 2017/2018 (b) , and 2019/2020(c) seasons. Data are presented as means \pm SDs and the different upper

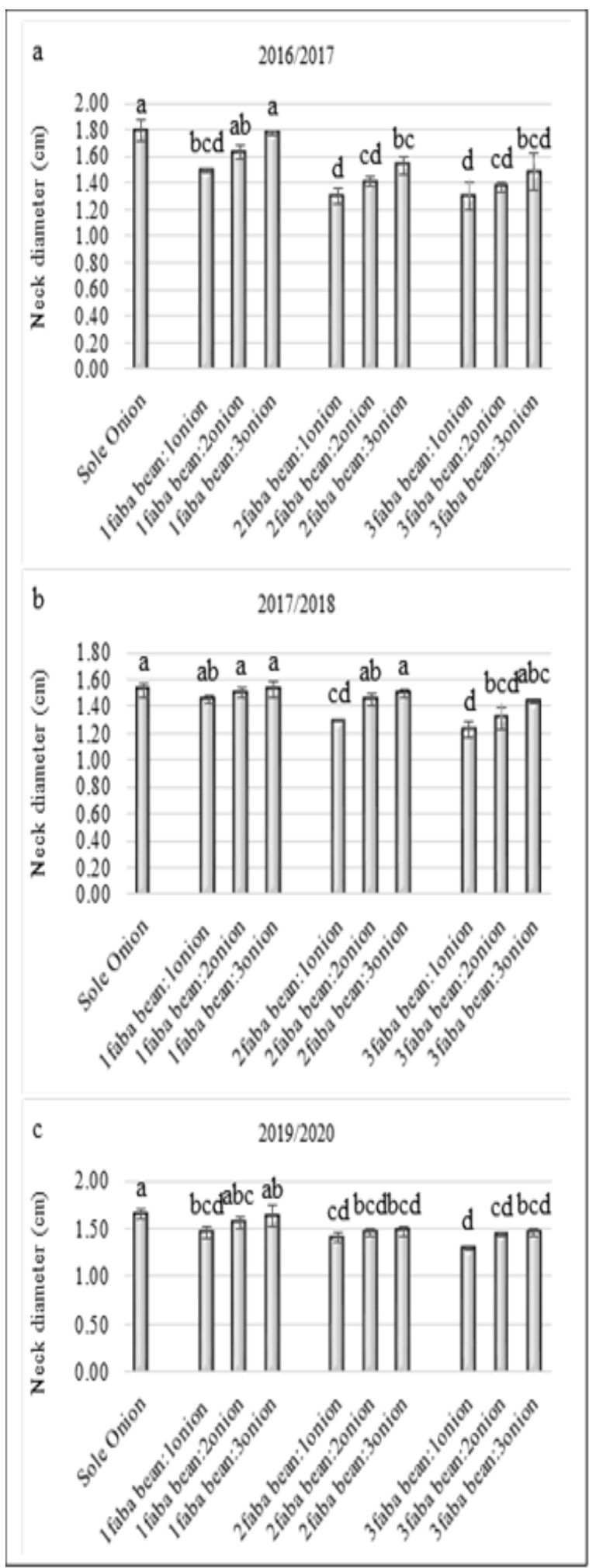

Fig 18. Influence of intercropping system on Neck diameter (cm)of dry Onion during 2016/2017(a), 2017/2018 (b) , and 2019/2020(c) seasons. Data are presented as means \pm SDs and the different upper letters indicate significant differences at $\mathrm{P}<0.05$ level according to the Tukey's test. 


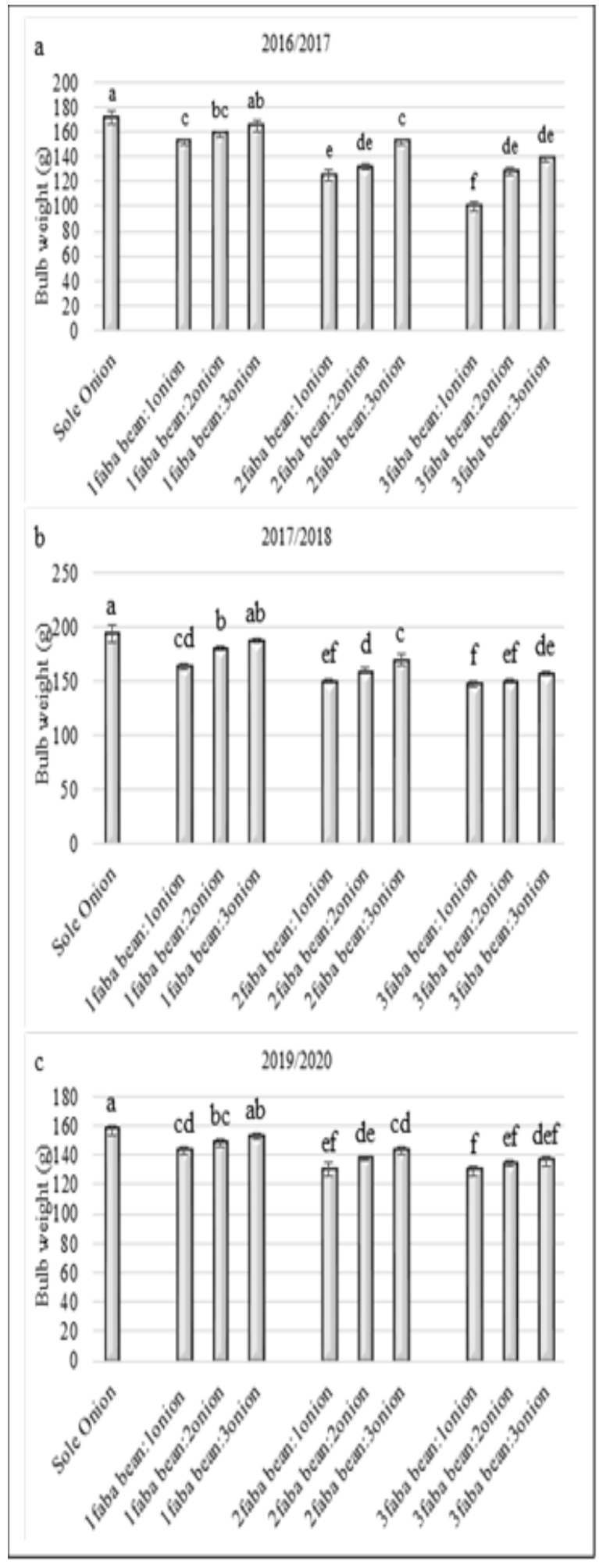

Fig 19. Influence of intercropping system on Bulb weight (g) of dry Onion during 2016/2017(a), 2017/2018 (b) , and 2019/2020(c) seasons. Data are presented as means \pm SDs and the different upper letters indicate significant differences at $\mathrm{P}<0.05$ level according to the Tukey's test.

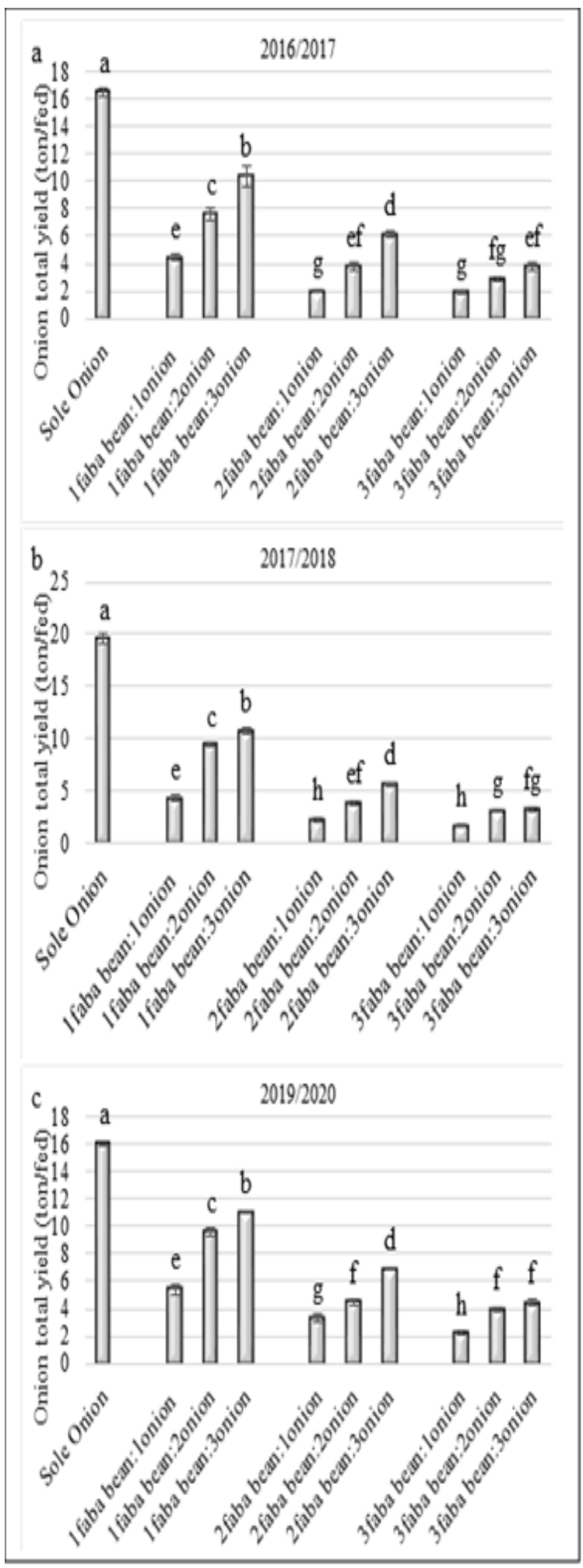

Fig 20. The total yield of onion as affected by the intercropping system during the $2016 / 2017,2017 / 2018$, and 2019/2020 seasons. Data are presented as means \pm SDs and the different upper letters indicate significant differences at $\mathrm{P}<0.05$ level according to the Tukey's test. 


\subsubsection{Onion biochemical chemical analysis.}

Nitrogen $(\mathrm{N})$, phosphorus $(\mathrm{P})$, and potassium $(\mathrm{K})$ percentages were determined for onion leaves under different intercropping systems, and data are illustrated in (Fig 21, 22 and 23). Results showed that with increasing the onion plants, nitrogen percentage was increased significantly during the growing seasons of 2016/2017, 2018/2019, and 2019/2020. The highest value of $\mathrm{N}$ was associated with sole onion in the three seasons, which were $1.47 \%$, $1.72 \%$, and $1.39 \%$ during the $1 \mathrm{st}, 2 \mathrm{nd}$, and $3 \mathrm{rd}$ seasons. No significant difference was found among sole onion and 1faba bean:2onion, 1faba bean:3onion, and 2 faba bean:3onion in the first and third seasons. However, with decreasing onion plants $\mathrm{N} \%$ was decreased, where, 2faba bean:1onion and 3faba bean 1onion recorded the lowest $\mathrm{N} \%$ during the three seasons.

Regarding to $\mathrm{P} \%$ and $\mathrm{K} \%$, presented data clarified that sole onion obtained the highest $\mathrm{P}$ and $\mathrm{K} \%$ during all seasons with no significant difference with 1faba bean:3onion and 1faba bean:2onion. Also, 3 faba bean:1 onion recorded the lowest percentage of $(\mathrm{P} \%)$ and $(\mathrm{K} \%)$ during study seasons.

\subsection{Land equivalent ratio (LER)}

The LER for all intercropping systems was calculated and data presented in Fig (24). The measurement of LER could be used as useful indicator of faba bean and onion intercropping. In general, LER value of all intercropping systems was less than 1 except 3 faba bean:1onion was more than 1 in all experiment seasons. The recorded value of LER for 3faba bean:1onion during first, second and third seasons were 1.249, 1.248 and 1.275 , respectively. This was followed by 1 faba bean:3onion, which were $0.999,0.923$ and 1.005 in the 2016/2017, 2017/2018 and 2019/2020 seasons, respectively.

\subsection{The Economic Efficiency}

This part of the research deals with the economic evaluation of the application of several treatments when cultivating the fava bean crop over the onion crop, by estimating some indicators of economic efficiency, including (B/C) Benefit / Costs Ratio: This ratio represents the value of revenues generated by an investment of one monetary unit of costs, and when this ratio is equal to or greater than one, economic efficiency is achieved, and when it is less than one, this indicates low Economic efficiency.

it was performed using the formula as follows:

$$
\begin{aligned}
\mathrm{B} / \mathrm{C} & =\frac{\mathrm{P} \times \mathrm{Q}}{\mathrm{Bi}} \\
& =\frac{\text { Benefit (revenue) }}{\mathrm{Bi}}
\end{aligned}
$$

Where: $\mathrm{P}$ is price (LE/Ton); Q is yield (ton/fed); and $\mathrm{Bi}$ is the production cost $(\mathrm{LE} / \mathrm{Fed})$

Return on investment (ROI)

Return on investment (ROI), is a profitability ratio that measures the gain or loss generated from an investment of using the same treatment, and it shows what the unit costs add to the net gain, was performed using the formula as follows:

$$
\mathrm{ROI}=\frac{\text { Net gains }}{\mathrm{Bi}}
$$

Where: Net gains $=$ Benefit (total revenue) minus total cost; and $\mathrm{Bi}$ is the production cost ( $\mathrm{LE} / \mathrm{Fed})$

The Ratio of net gain increase (NGI) The ratio of the net return from applying transactions to the net return from the traditional farming method, was performed using the formula as follows:

$$
\text { NGI }=\frac{\text { NG IT }}{\text { NGTP }}
$$

Where: NGI is net gain increase; NGIT is net gains from Treatment application; NGTP is net gains from farmer implementation 


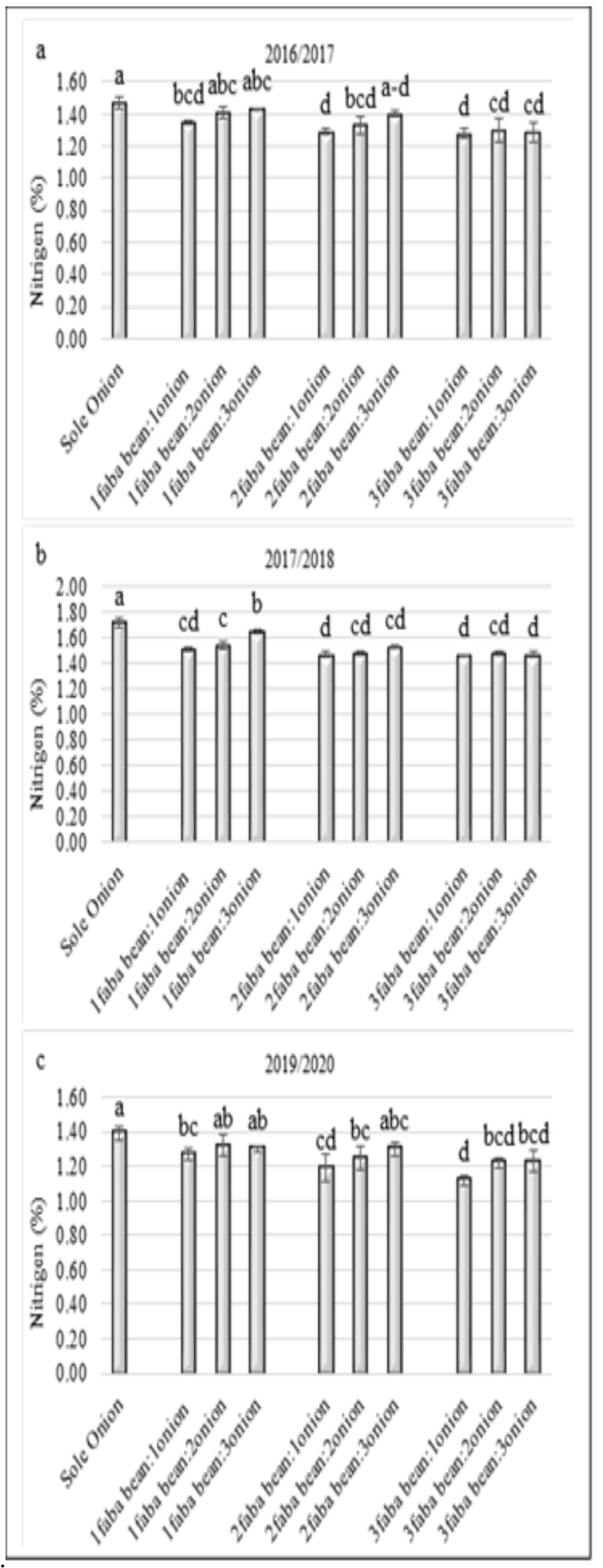

Fig 21. Influence of intercropping system on N\%, of Onion during 2016/2017(a), 2017/2018(b), and 2019/2020(c) seasons. Data are presented as means \pm SDs and the different upper letters indicate significant differences at $\mathrm{P}<0.05$ level according to the Tukey's test.

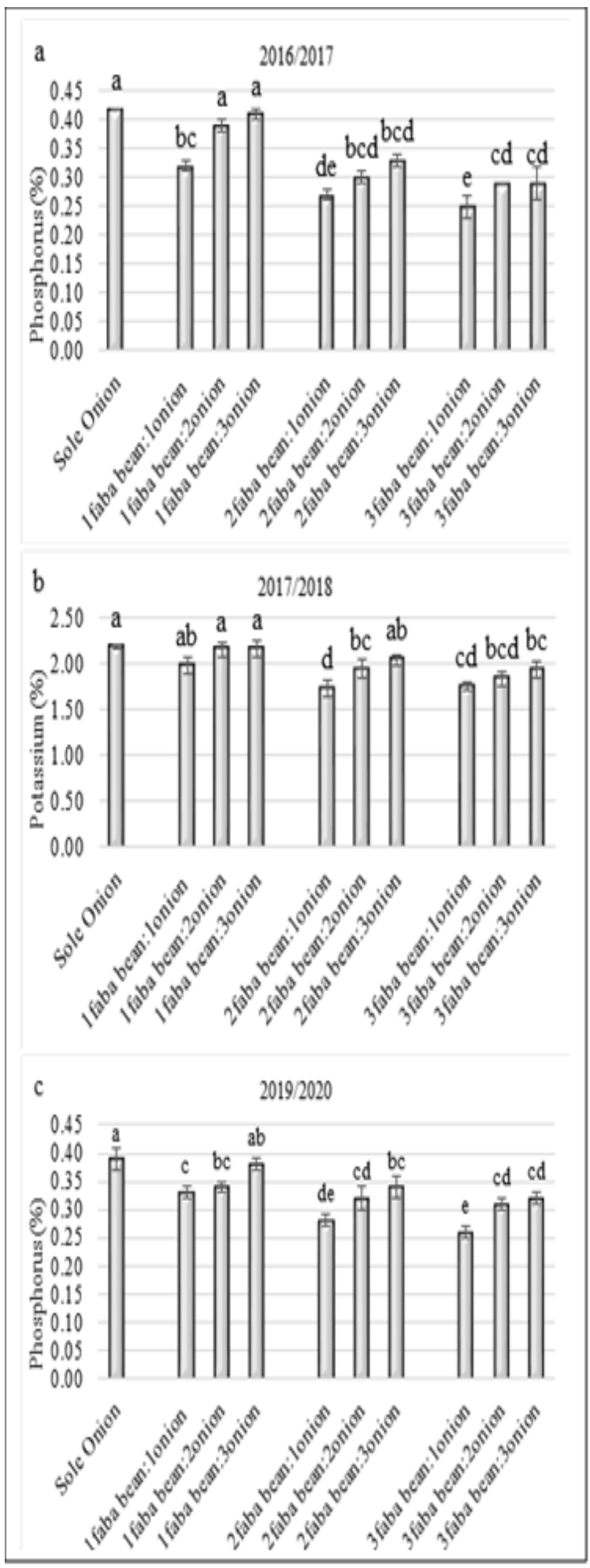

Fig 22. Influence of intercropping system on P\%, of Onion during 2016/2017, 2017/2018, and 2019/2020 seasons. Data are presented as means \pm SDs and the different upper letters indicate significant differences at $\mathrm{P}<0.05$ level according to the Tukey's test. 


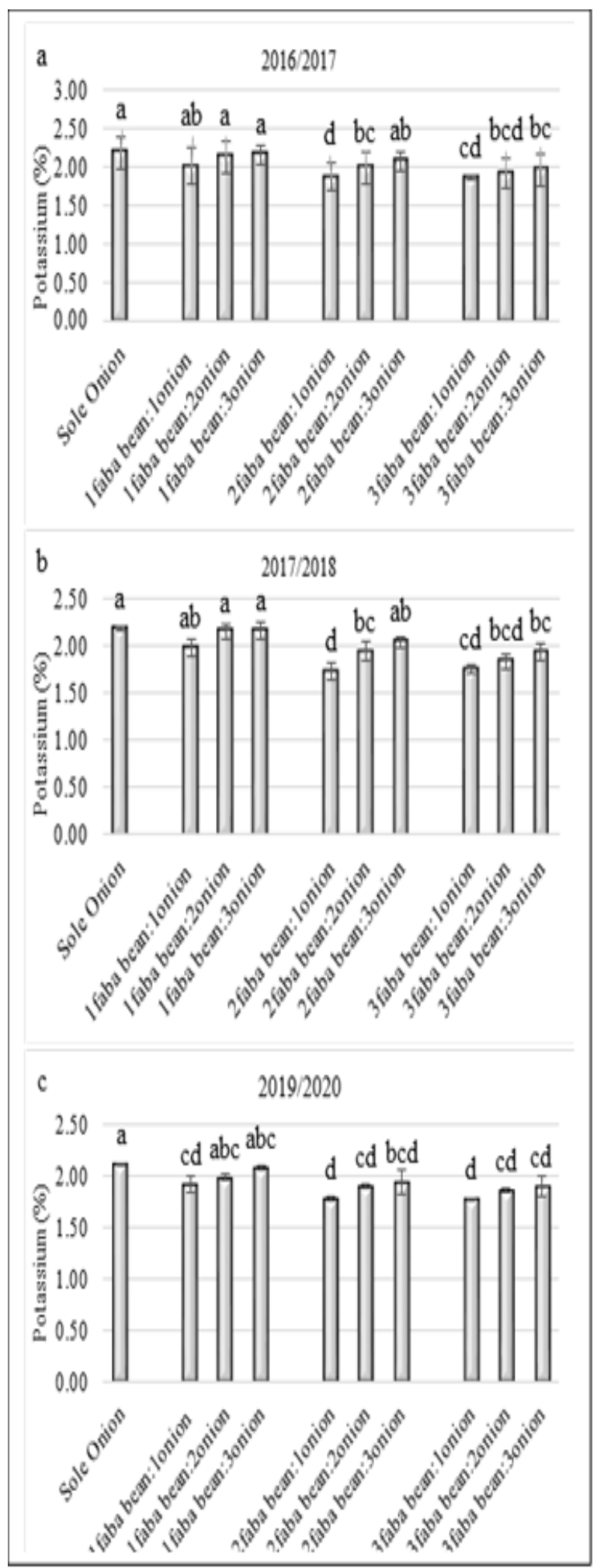

Fig 23. Influence of intercropping system on $\mathrm{K} \%$ of Onion during 2016/2017, 2017/2018, and 2019/2020 seasons. Data are presented as means \pm SDs and the different upper letters indicate significant differences at $\mathrm{P}<0.05$ level according to the Tukey's test.

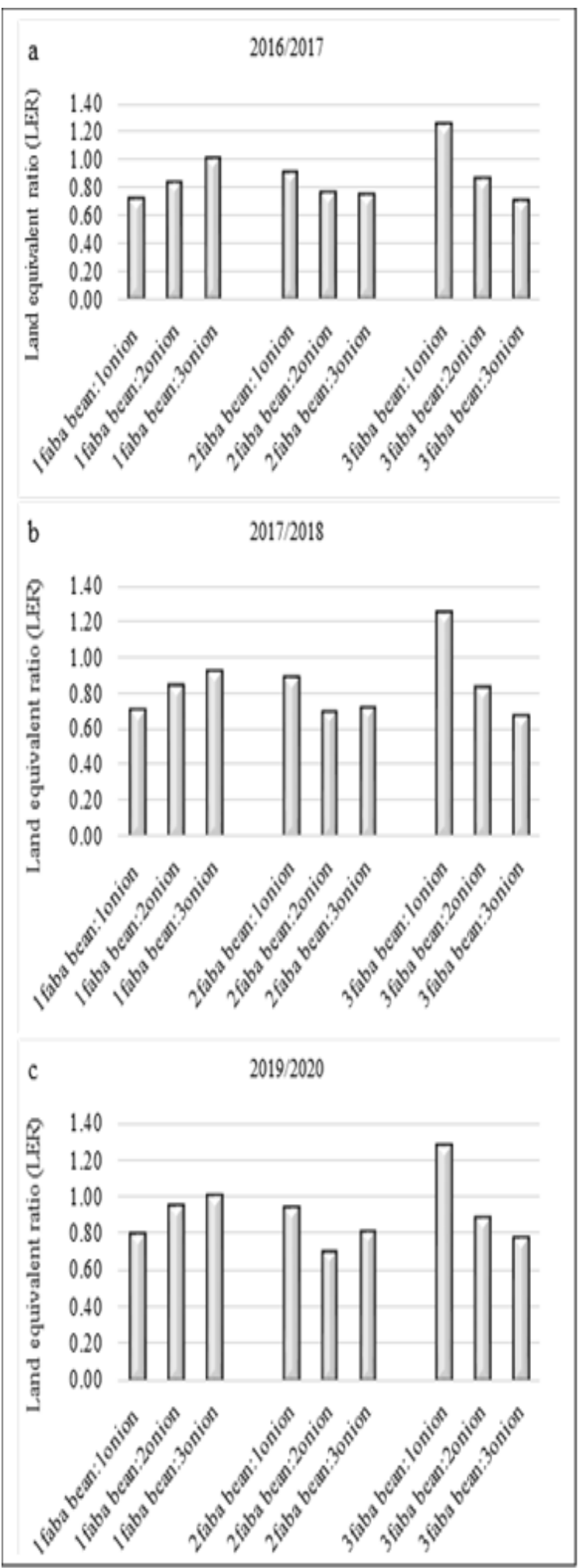

Fig 24. Influence of Land equivalent ratio (LER) during the 2016/2017 (a), 2017/2018 (b) , and 2019/2020(c) seasons. Data are presented as means \pm SDs and the different upper letters indicate significant differences at $\mathrm{P}<0.05$ level according to the Tukey's test. 


\subsubsection{First: The Economic Indicators for Experiment Treatment}

By reviewing the data in Table No. (2), which shows the economic indicators criteria for producing the fava bean crop loaded on onions during the three growing seasons, it is clear that cultivating the fava bean crop loaded on onions using the third treatment ( 3 onion: 1 faba bean) achieves the highest Benefit and net gain per fedan. It amounted to 25.517, 17.771thousand pounds respectively as average of the three cultivation seasons, although the seventh treatment has the lowest costs than other experimental treatments.

Table 2. The Economic Indicators for Experiment Treatment

\begin{tabular}{|c|c|c|c|}
\hline TREATMENT & \multicolumn{3}{|c|}{ Net gains Benefit* (revenue) TOTAL COST } \\
\hline CONTROL FABA BEAN & 7989.98 & 11956.08 & 3966.1 \\
\hline CONTROL ONION & 29859.23 & 35331.33 & 5472.1 \\
\hline $\begin{array}{l}\text { TREATMENT } 1 \\
\text { (1 BEAN:1 ONION) }\end{array}$ & 6917.33 & 15105.53 & 8188.2 \\
\hline $\begin{array}{l}\text { TREATMENT } 2 \\
\text { (1 BEAN:2 ONION) }\end{array}$ & 14693.25 & 22356.45 & 7663.2 \\
\hline $\begin{array}{l}\text { TREATMENT } 3 \\
\text { (1 BEAN:3 ONION) }\end{array}$ & 17771.39 & 25517.09 & 7745.7 \\
\hline $\begin{array}{c}\text { TREATMENT } 4 \\
\text { (2 BEAN:1 ONION) }\end{array}$ & 6584.69 & 14147.89 & 7563.2 \\
\hline $\begin{array}{l}\text { TREATMENT } 5 \\
(2 \text { BEAN:2 BEAN) }\end{array}$ & 4919.60 & 13805.41 & 8183.2 \\
\hline $\begin{array}{l}\text { TREATMENT } 6 \\
\text { (2 BEAN:3 ONION }\end{array}$ & 9923.65 & 17324.35 & 7400.7 \\
\hline $\begin{array}{l}\text { TREATMENT } 7 \\
\text { (3 BEAN:1 ONION) }\end{array}$ & 10374.63 & 17562.83 & 7188.2 \\
\hline $\begin{array}{c}\text { TREATMENT } 8 \\
\text { (3 BEAN:2 ONION) }\end{array}$ & 7131.18 & 14642.38 & 7511.2 \\
\hline $\begin{array}{l}\text { TREATMENT } 9 \\
\text { (3 BEAN:3 ONION) }\end{array}$ & 5414.17 & 13677.37 & 8263.2 \\
\hline
\end{tabular}

\footnotetext{
* According to the price per ton of bean=7000 LE, for onion=2039 LE

Source:

1- Calculated from: The results of the research experiment.
}

\subsubsection{Second: The Indicators of Economic Efficiency for Experiment Treatment}

By reviewing the data in Table No. (3), which shows the economic efficiency criteria, It is clear that the cultivation of the fava bean crop loaded on onions using the third treatment ( 3 onions: 1 faba bean) achieves the highest $\mathrm{B} / \mathrm{C}$ ratio, reaching 3.29 as average of the three cultivation seasons. It is also clear that each pound invested in the cultivation of faba bean, loaded on onions using this third treatment ( 3 onion: 1 faba bean), achieves a return of 2.28 pounds as average of the three cultivation seasons. Where it achieved the Return on investment (ROI).

Table 3. The Indicators of Economic Efficiency for Experiment Treatment

\begin{tabular}{|c|c|c|c|c|}
\hline TREATMENT & NGI(onion) & NGI(bean) & ROI & $\mathrm{B} / \mathrm{C}$ \\
\hline $\begin{array}{l}\text { TREATMENT } 1 \\
\text { (1 BEAN:1 ONION) }\end{array}$ & 0.23 & 0.85 & 0.83 & 1.83 \\
\hline $\begin{array}{c}\text { TREATMENT } 2 \\
(1 \mathrm{BEAN}: 2 \text { ONION })\end{array}$ & 0.49 & 1.83 & 1.9 & 2.91 \\
\hline $\begin{array}{c}\text { TREATMENT } 3 \\
\text { (1 } \mathrm{BEAN}: 3 \text { ONION })\end{array}$ & 0.59 & 2.22 & 2.28 & 3.29 \\
\hline $\begin{array}{c}\text { TREATMENT } 4 \\
(2 \text { BEAN :1 ONION ) }\end{array}$ & 0.22 & 0.81 & 0.85 & 1.86 \\
\hline $\begin{array}{c}\text { TREATMENT } 5 \\
(2 \text { BEAN :2 ONION ) }\end{array}$ & 0.49 & 0.7 & 0.68 & 1.68 \\
\hline $\begin{array}{c}\text { TREATMENT } 6 \\
\text { (2 BEAN:3 ONION) }\end{array}$ & 0.33 & 2.22 & 1.33 & 2.33 \\
\hline $\begin{array}{l}\text { TREATMENT } 7 \\
\text { (3 BEAN:1 ONION) }\end{array}$ & 0.34 & 1.29 & 1.44 & 2.44 \\
\hline $\begin{array}{l}\text { TREATMENT } 8 \\
\text { (3 BEAN:2 ONION) }\end{array}$ & 0.23 & 0.88 & 0.94 & 1.94 \\
\hline $\begin{array}{c}\text { TREATMENT } 9 \\
\text { (3 BEAN:3 ONION) }\end{array}$ & 0.18 & 0.66 & 0.64 & 1.64 \\
\hline
\end{tabular}

2- Ministry of Agriculture and Land Reclamation, Economic Affairs Sector,

Central Administration of Agricultural Economy, Bulletin of Agricultural

Economics,2018/2019. 


\section{Source:}

Calculated from table (2).

By comparing the ratio of the net return from applying the treatment to the net return from the traditional farming method (faba bean), it is also found that this third treatment ( 3 onion: 1 faba bean) achieves the highest net return compared to the cultivation of the bean (traditional) than other treatments in the experiment, as The net return achieved achieved from it is higher than the traditional farming system by 2.22 , as average of the three cultivation seasons.

By comparing the ratio of the net return from applying the treatment to the net return from the traditional cultivation method (single onions), it is also found that this third treatment ( 3 onion: 1 faba bean) achieves the highest net return compared to the cultivation of single onions (traditional) than other treatments in the experiment, as The net return achieved from it exceeds the traditional farming system by 0.59 , as average of the three cultivation seasons.

\section{Discussion}

The positive effects that can result from intercropping system is the complementarity between crops that are intercropped compared to when they are grown separately. Selecting crop species grown in an intercrop that are differences in rooting depth, phenology, and vegetative architecture can minimize competition and increase resource partitioning (Litrico and Violle, 2015; Bybee-Finley and Ryan, 2018). In the current experiment, faba bean and onion used as planting patterns exhibited a significant positive effect on the production and nutrient uptake than sole grow. Onion vegetative parameters, yield and yield components significantly increased with intercropping system 1faba bean:3onion compared to other intercropping systems. The decrease in faba bean density produced bulbs with bigger diameter. This result in agreement with Mota et al. (2012) who showed that increase density of lettuce plants resulting in bulbs with smaller diameters and could be attributed to lettuce shading over onion was higher at lower onion densities. In contrast, 3faba bean:1onion has high positive impact for faba bean yield than other intercropping systems and less onion yield may be attributed to shading by more faba bean plants. Similar yield promoting effect had been noticed in other intercropping systems i.e. cucumber with onion or garlic (Zhou et al., 2011). Meanwhile, Abou-keriasha et al. (2013) reported that the plant height, yield and yield components of faba bean, onion and wheat were decreased under intercropping system. Previous studies indicated that nitrogen fixing legumes i.e. bean contribute to maintain soil fertility and can be included in intercropping systems and this can lead to enhance nitrogen use efficient and complementary between crop species in intercropping system (Nyasasi and Kisetu, 2014; Pour et al., 2016). Yildirim and Guvenc (2003) reported that net income increased when used cos lettuce, bean, leaf lettuce or onion as intercrop. Intercropping sugar beet with $25 \mathrm{~cm}$-onion maximized the income of farmers and reduced insect pest infestations as reported by Badawy and Shalaby (2015). Moreover, Morsy et al. (2009) indicated that intercropping cucumber with onion enhanced leaf number and number of flowers/plant in cucumber. As reported by Mahdi et al. (2011) sown bean with onion and garlic was the best manner for productivity per unit area comparing with sole bean. Moreover, our results confirmed that land equivalent ratio (LER) was higher (with average of 1.26 over three seasons) with 3faba bean:1onion intercropping system compared to other systems. Sullivan (2003) mentioned that 1.25 LER value revealed that the obtained yield in the total intercrop would have required $25 \%$ more land if planted in pure stands. Also, Islam et al. (2015) showed that LER of various crop combination ranged from 1.54 to 2.29 indicating $54-129 \%$ yield advantage by 
intercropping. High LER proportion might be attributed to the difference in time and place in ecological niche and consumption of nutrients and water. Previously Strydhorst et al. (2008) reported that legumes compared to cereal species are often less competitive and may require higher planting densities to achieve intercropping benefits. The obtained results were in harmony with Abou-Keriasha et al. (2013) who reported that the LER was greater when intercropping faba bean and onion. In addition, onion showed highest value of LER when intercropped with other crops i.e. sugar beet (Farghaly et al., 2003). Also, Abdel-Motagally and Metwally (2014) confirmed that intercropping onion with sugar beet gave the greatest economic return for farmers and recorded the highest LER value compared to sole crops of either species. Onion and faba bean planting together is a common agricultural phenomenon, however, less consideration has been given to major nutrient $(\mathrm{N}, \mathrm{P}$ and $\mathrm{K})$ contents in their various intercropping systems. In this investigation, $\mathrm{N}, \mathrm{P}$ and $\mathrm{K}$ percentages of onion and faba bean varied in different intercropping system. Similar trend was reported by Moghbeli et al. (2019) where concentration and uptake of $\mathrm{N}, \mathrm{P}$ and $\mathrm{K}$ of onion leaf and bulb and fenugreek under intercropping system were increased in compare with mono cropping of two species. Previous studies showed that some intercropping systems can improve soil quality and ecological microclimate, and stimulate population of microorganisms and improve soil biology (Li et al., 1999; Xiao et al., 2012), which suggests that this intercropping system can enhance nutrient uptake and reduce the input of chemical fertilizer. Moreover, several studies mentioned that the amount and type of root exudates differ between plant species, and these differences can stimulate species-specific shifts in the soil microbial community (Welbaum et al., 2004; Singh et al., 2007; Xu et al., 2009). Zhang et al. (2013) revealed that under intercropping treatment, interactions of root could raise the root extent and microbial activity in rhizospere. Enzyme activity of soil is very important for soil quality, which could provide an indicators of changes in metabolic capacity and nutrient cycling (Zhou et al., 2011). Continuous monoculture of cucumber resulted in significantly decreased of soil catalase, urease and invertase activities (Wu et al., 2006). Results of Li et al. (2009) pointed that the nodule biomass and nitrogen derived from air in intercropped faba bean were increased by $7-58 \%$ and $8-33 \%$ at the beginning of flowering, $8-72 \%$ and $54-61 \%$ at peak flowering, $4-73 \%$ and $18-50 \%$ at grain filling, and $7-62 \%$ and $7-72 \%$ at maturity stage, respectively in compare with sole faba bean. Similar results were observed by Li et al. (2001) confirmed the interspecific facilitation of nodulation of legumes.

The obtained results of current investigation might be showed that successful intercropping system could be occur when each crop occupies and accesses resources from different ecological niches while reducing competitive interactions. This was in agreement with (Getahun et al., 2018) who indicated that legumes are more advised for intercropping with onion if the competition with the main crop is not adverse bringing about value of LER below one.

\section{Conclusion}

From this study it could be concluded that, the intercropping system of 3 faba bean: 1onion or 1 faba bean: 3onion could be the suitable model to obtain the greatest use efficiency of land and irrigation water.

\section{References}

Abdel Motagally F.M.F. and Metwally, A.K. 2014 'Maximizing Productivity by Intercropping Onion on Sugar Beet' Asian Journal of Crop Science, 6: 226235. 
Abou-Keriasha, M.A., Eisa, N.M.A and ElWakil, N.M.H. (2013) 'Effects of intercropping faba bean on onion and wheat with or without inoculated bacteria on yield of the three crops' Egypt. J. Agron., 35(2): 169-182.

Analytical software, (2005) 'Statistix 8.1 for Windows analytical software' Tallahassee, Florida.

Badawy, S.A.E. and Shalaby, G.A. (2015) 'Effect of intercropping of sugar beet with onion and garlic on insect infestation, sugar beet yield and economics' J. Plant Production, Mansoura Univ., 6 (6): 903-914.

Bybee-Finley, K.A., and Ryan, M.R. (2018) 'Advancing intercropping research and practices in industrialized agricultural landscapes' Agriculture, 8(6), 80. Doi:10.3390/agriculture8060080.

Chen, W., Liu, H. (2015) 'Intracellular nitrite accumulation: the cause of growth inhibition of Microcystisaeruginosa exposure to high nitrite level' Phycological Res., 63:197-201.

DOI: 10.3923/ajcs.2014.226.235.

El-Beltagy, A.T. and Abou Hadid, A.F. (2008) 'The main pillars of the National Program for maximizing the water-use efficiency in the old land' The Research and Development Council. Moalr. (in Arabic); p. 30.

El-Kholy, A.S.M., Aly, R.M.A., El-Bana, A.Y.A. and Yasin, M.A.T. (2019) 'Yield of faba bean (Vicia faba L.) as influenced by planting density, humic acid rate and phosphorus fertilization level under drip irrigation system in sandy soils' Zagazig J. Agric. Res., 46(6A).
Farghaly, B.S., Zohry, A.A. and Bassal, S.A.A. (2003) 'Crops management for intercropping sugar beet with some essential crops to maximize area unit productivity' J. Agric. Sci. Mansoura Univ., 28(7): 5183- 5199.

Getahun, D., Getaneh, M. and Habte, B. (2018) 'Companion crops for intercropping with onion production in the dry season at Fogera district of south Gondar zone in Ethiopia' International J. of Research Studies in Agricultural Sciences, 4 (4): 17-24.

DOI: http://dx.doi.org/10.20431/24546224.0404003.

Goyal, S.S., Tischner, R. and Basra, A.S. (2005) 'Enhancing the efficiency of nitrogen utilization in plants' Haworth Press, Inc, Haworth, p 489.

Hefzy, M., Mostafa, H.H.A. and Zahran, M.M.A.A. (2020) 'Enhancement of onion (Allium cepa L.) drought tolerance in calcareous soils by using biostimulants' Environment, Biodiversity \& Soil Security, 4: 239-251. DOI: 10.21608/jenvbs.2020.41196.1104.

Islam, M.R., Mian, M.A.K., Mahfuza, S.N., Hossain, J. and Hannan, A. (2015) 'Efficiency of intercropping vegetables and spices relayed with pointedgourd' Bangladesh Agron. J. 18(1): 7-12.

Jackson, M.L. (1973) 'Soil chemical analysis' 2nd Ed., Prentice Hall of Indian Private Limited, New Delhi.

Jones, T.A., Zou, J.Y., Cowan, S.W. and Kjeldgaard, M. (1991) 'Improved methods for building protein models in electron density maps and the location of errors in these models' Acta Crystallographica Section A Foundations of Crystallography, 47(2), 
110-119. doi:10.1107/s0108767390010224.

Li, L., Sun, J.H., Zhang, F.S., Li, X.L., Yang, S.C. and Rengel, Z. (2001) 'Wheat/ maize or wheat/soybean strip intercropping. I. Yield advantage and interspecific interactions on nutrients' Field Crops Res., 71:123-137 doi:10.1016/S03784290(01)00156-3.

Li, Y.Y., Yu, C.B., Cheng X., Li, C.J., Sun, J.H., Zhang, F.S., Lambers, H. and Li, L. (2009) 'Intercropping alleviates the inhibitory effect of $\mathrm{N}$ fertilization on nodulation and symbiotic N2 fixation of faba bean' Plant Soil, 323: 295-308. DOI 10.1007/s11104-009-9938-8.

Li, L., Yang, S.C., Li, X.L., Zhang, F.S. and Christie, P. (1999) 'Interspecific complementary and competitive interactions between intercropped maize and faba bean' Plant Soil, 212: 105-114.

Litrico, I.; Violle, C. (2015) 'Diversity in plant breeding: A new conceptual framework' Trends Plant Sci., 20: 604-613.

Mahdi A.S., Mahmood N.A. and Hammad H.S. (2011) 'Effect of intercropping and agricultural periods into some winter vegetable crops for the quantitative characteristics on broad bean Vicia faba L. var. acwadlgy' Researches of the First International Conference (Babylon and Razi Universities).

Moghbeli, T., Bolandnazar, S., Panahande, J. and Raei, Y. (2019) 'Effects of additive intercropping on mineral uptake of onion and fenugreek at different densities' Journal of Agricultural Sciences, 25: 238-246..

Morsy, S. M., Drgham, E. A.,and Mohamed, G. M. (2009). Effect of garlic and onion extracts or their intercropping on suppressing damping-off and powdery mildew diseases and growth characteristics of cucumber' Egyptian Journal of Phytopathology, 37(1), 35-46.

Mostafa, H.H.A., Li, B., Zhu, X. and Son, C. (2021) 'Nitrogen assimilation under osmotic stress in maize (Zea mays L.) seedlings' Plant Growth Regulation, 94: 87-99. https://doi.org/10.1007/s10725021-00698-5.

Mota, W.F., Pereira, R.D., Santos, G.S. and Vieira, J.C.B. (2012) 'Agronomic and economic viability of intercropping onion and lettuce' Horticultura Brasileira, 30 (2): 349-354.

Nyasasi, B.T., Kisetu, E. (2014) 'Determination of land productivity under maize-cowpea intercropping system in agro-ecological zone of Mount Uluguru in Morogoro, Tanzania' Global Science research Journal. 2(2),147-157.

Olfati, J.A. and Malakouti, S.H. (2013) 'Pinching can increase faba bean yield and yield characteristics' International Journal of Vegetable Science, 19 (3): 203-206. DOI:10.1080/19315260.2012.697108.

Parkinson, J.A. and Allen, S.E. (1975) 'A wet oxidation procedure suitable for the determination of nitrogen and mineral nutrients in biological materials' Commun. Soil Sci. and Plant Analysis, 6: 1- 11.

Peters, J., Combs, S., Hoskins, B., Jarman, J., Kovar, J., Watson, M., ... and Wolf, N. (2003). Recommended methods of manure analysis. University of Wisconsin Cooperative Extension Publishing: Madison, WI. 
Pour, A.H., Mahalleh, J.K., Tabrizi, H.Z. and Valilue, R. (2016) 'Evaluation of yield and yield components in intercropping of maize and green bean' Yuzuncu Yil University Journal of Agricultural Sciences, 26 (1): 68-78.

Raza, M.A., Bin-Khalid, M.H., Zhang, X., Feng, L.Y., Khan, I., Hassan, M.J., Ahmed, M., Ansar, M., Chen, Y.K., Fan, Y.F., Yang, F. and Yang, W. (2019) 'Effect of planting patterns on yield, nutrient accumulation and distribution in maize and soybean under relay intercropping systems' Scientific Reports, 9(1). https://doi.org/10.1038/s41598-01941364-1.

Refai, E.F.S, Mostafa, H.H.A., Hefzy, M. and Zahran, M.M.A.A. (2019) 'Enhance of water use efficiency, productivity and quality of lettuce (Lactuca sativa L.) on newly reclaimed soils' Middle East Journal of Applied Sciences, 9 (2): 464473.

Singh, B.K., Munro, S., Potts, J.M. and Millard, P. (2007) 'Influence of grass species and soil type on rhizosphere microbial community structure in grassland soils' Appl. Soil Ecol. 36: 147e155.

Strydhorst, S.M., King, J.R., Lopetinsky, K.J. and Harker, K.N. (2008) 'Forage potential of intercropping barley with faba bean, lupin, or field pea' Agronomy J., 100 (1): 182-190. doi:10.2134/agronj2007.0197.

Sullivan, P. (2003) 'Intercropping Principles and Production Practices,Agronomy Systems Guide’ Appropriate Technology Transfer for Rural Areas (ATTRA): http://attra.ncat.org/attrapub/intercrop.html.
Welbaum, G.E., Sturz, A.V., Dong, Z. and Nowak, J. (2004) 'Managing soil microorganisms to improve productivity of agro-ecosystems, Crit' Rev. Plant Sci. 23: $175 \mathrm{e} 19$.

Willey, R.W. (1979) 'Intercropping its importance and research needs' Part 1: Competition and yield advantages Field Crops Abst., 32: 1-10.

Wu F.Z., Meng, L.J. and Wang, X.Z. (2006) 'Soil enzyme activities in vegetable rotation and continuous cropping system of under shed protection' Plant Nut. Fert. Sci. 12 $554 \mathrm{e} 558$

Xiao, X., Cheng, Z., Meng, H., Khan, M.A. and $\mathrm{Li}, \mathrm{H}$. (2012) 'Intercropping with garlic alleviated continuous cropping obstacle of cucumber in plastic tunnel. Acta Agriculture Scandinavia Sectin B' Soil and Plant Science, 62: 696=705.

Xu, Y., Wang, G., Jin, J., Liu, J., Zhang, Q. and Liu, X. (2009) 'Bacterial communities in soybean rhizosphere in response to soil type, soybean genotype, and their growth stage' Soil Biol. Biochem, 41 919e925.

Yildirim, E., and Guvenc, I. (2005) 'Intercropping based on cauliflower: more productive, profitable and highly sustainable' European Journal of Agronomy, 22(1), 11-18.

Zahran, M.M.A.A., Hefzy, M. and Mostafa, H.H.A. (2020) 'Enhancing the productivity of potato crop under drought stress by using some biological treatments' International Journal of Environment 9 (2): 83-103. DOI: 10.36632/ije/2020.9.2.6.

Zhang, X., Huang, G., Bian, X. and Zhao, Q. (2013) 'Effects of root interaction and nitrogen fertilization on the root activity, 
photosynthetic characteristic so intercropped soybean and microbial quantity in the rhizosphere' Plant Soil Environment, 59(2): 80-88.

Zhou, X., Yu, G. and Wu, F. (2011) 'Effects of intercropping cucumber with onion or garlic on soil enzyme activities, microbial communities and cucumber yield' European Journal of Soil Biology, 47(5), 279-287. doi:10.1016/j.ejsobi.2011.07.001. 